
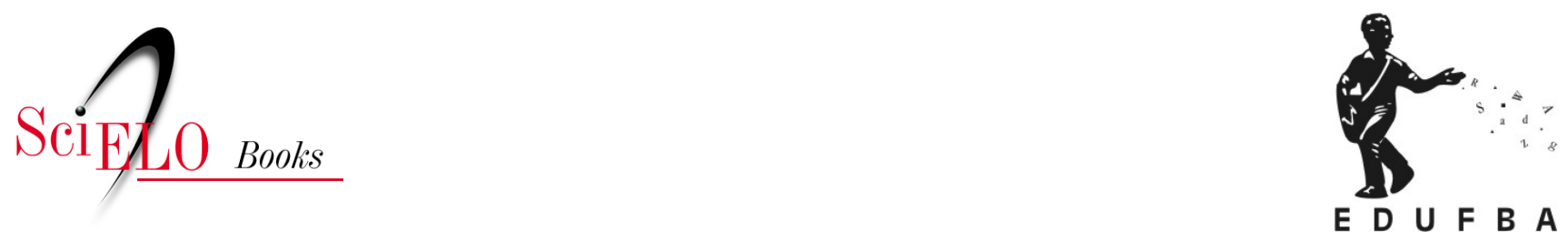

\title{
A propósito da visualidade na cena
}

\author{
Eduardo Tudella
}

\section{SciELO Books / SciELO Livros / SciELO Libros}

TUDELLA, E. A propósito da visualidade na cena. In: A luz na gênese do espetáculo [online].

Salvador: EDUFBA, 2017, pp. 41-79. ISBN: 978-85-232-1858-4.

https://doi.org/10.7476/9788523218584.0003.

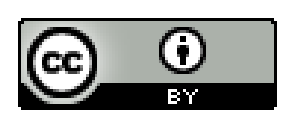

All the contents of this work, except where otherwise noted, is licensed under a Creative Commons Attribution $\underline{4.0 \text { International license. }}$

Todo o conteúdo deste trabalho, exceto quando houver ressalva, é publicado sob a licença Creative Commons Atribição 4.0.

Todo el contenido de esta obra, excepto donde se indique lo contrario, está bajo licencia de la licencia Creative Commons Reconocimento 4.0. 


\title{
A PROPÓSITO DA VISUALIDADE NA CENA
}

\begin{abstract}
A presente investigação inclui uma abordagem particular de dois termos muito similares, visibilidade e visualidade. Hall Foster, crítico de arte e historiador, membro da Academia Norte-Americana de Artes e Ciências, oferece, no prefácio de Vision and visuality, um caminho que pode contribuir para o tema:

Embora o termo visão sugira o ato de ver como uma operação física, e visualidade como um fato social, os dois não se opõem, como aspectos da natureza, à cultura: a visão é social e também histórica, e a visualidade envolve o corpo e a mente ${ }^{1}$ (FOSTER, 1988, p. IX, tradução nossa)
\end{abstract}

\footnotetext{
1 "Although vision suggests sight as a physical operation, and visuality sight as a social fact, the two are not opposed as nature to culture: vision is social and historical too, and visuality involves the body and the psyche."
} 
Ele pondera que, além de não serem idênticos, esses conceitos assinalam uma tensão positiva no interior do processo visual, ou seja: uma tensão que faz interagir o mecanismo da visão, suas técnicas históricas, os dados da visão e suas determinações discursivas, com muitas diferenças entre como podemos ver, como somos capazes, permitidos, ou levados a ver, como compreendemos esse ver, ou como encaramos seu interno invisível.

O termo visibilidade será aqui aplicado para referência esquemática à sensibilização do aparelho óptico humano, como resultado da incidência de luz sobre um objeto. Ou seja, quando um autor descreve ou sugere na sua peça uma fonte de luz, ele está incluindo - mesmo que intuitivamente - aspectos técnicos relacionados ao aparato e estabelecendo graus de visibilidade, numa relação direta com a capacidade humana de ver. Tais aspectos técnicos têm função ativa na compreensão da qualidade visual proposta pela dramaturgia. Essa qualidade visual incorpora também aspectos estéticos e poéticos que, presentes já na dramaturgia e interagindo com a visibilidade, promovem a visualidade.

Nos termos que serão aqui aplicados, fica estabelecido um espaço teórico-prático para que se reconheçam diferenças entre os termos visibilidade e visualidade. Ou seja: ainda que o acionamento da visão, através da adição de luz, torne a cena "visível", tal operação "física" resultará na visualidade do espetáculo, mesmo que essa visualidade não atenda a quaisquer critérios artísticos. A visualidade, como abordada no presente trabalho, portanto, está relacionada à postura crítica que orienta o iluminador e confere qualidade estética à sua contribuição para a práxis cênica.

Desse modo, projetar luz sobre a cena promoverá visibilidade. A avaliação de cada um dos aspectos técnicos, estéticos e poéticos de tal ação, identifica a visualidade de um espetáculo, ou a qualidade das imagens (cênicas) que suscitam a articulação do seu discurso poético-visual.

Assim, na práxis cênica, os aspectos constitutivos da visibilidade (as fontes de luz e os corpos sobre os quais elas incidem, nas condições específicas do ambiente) contribuem para a qualidade visual, ou visualidade, já indicada pela dramaturgia (ou por outro ponto de partida qualquer que origine um espetáculo), sendo perpassada por variáveis estéticas e poéticas. Tais variáveis incluem os traços de períodos, de estilos, do ideário que provoca e constitui a poética de cada artista.

O termo dramaturgia foi usado acima como referência às diversas possibilidades de estímulos que geram um evento espetacular. Também se poderia dizer que qualquer evento provocador, qualquer manifestação que leve o artista a conceber um espetáculo, já incorpora aspectos da visibilidade e da visualidade. 
Lendo um texto ou roteiro de um espetáculo, o artista já pode apreender sua qualidade visual, sem a necessidade da operação física de qualquer mecanismo de iluminação que promova visibilidade, mas compreendendo a natureza da abordagem de cada autor, das relações entre fontes de luz sugeridas ou descritas, e o ambiente da ação. Não será necessária a presença efetiva da luz do sol; nem mesmo uma lâmpada ou, sequer, uma vela. A ideia de espetáculo (uma espécie de estado pré-cênico) pode estar sendo narrada por alguém que a mantém na memória, e a narrativa, em si, já incorpora qualidades visuais. O iluminador pode apreender tais qualidades, ampliando sua abordagem da visualidade na práxis cênica. No escopo da imagem cênica, esse estado pré-cênico é encontrado em qualquer indício da ideia de um espetáculo. Ele pode se referir a uma tragédia grega ou a uma sutil elaboração mental engendrada na imaginação de um performer da nossa atualidade, no preciso momento em que ele decide responder a qualquer que seja o estímulo, nos termos da performatividade.

No espetáculo, contudo, a visibilidade incorpora objetivamente fontes de luz especificamente definidas pelo iluminador. Isso exige a análise de instâncias tecnológicas que incluem as características de cada instrumento, de cada acessório e do sistema de controle incluído no projeto, permitindo ao iluminador discutir a visualidade presente nas primeiras indicações da dramaturgia, como estratégia para definir aquela mais tarde efetivamente incorporada à cena propriamente dita.

Por outro lado, é importante salientar, na presente abordagem, que, ao apresentar visibilidade própria, toda práxis cênica estabelece um nível de visualidade, ou seja: a visualidade não representa um privilégio do "bom" espetáculo. Então, o modo como um iluminador aplica a visibilidade para construir a narrativa visual do espetáculo, que constitui o seu discurso visual, determinará a qualidade da proposição artística. Esclarecendo: mesmo um acontecimento cênico no qual proliferaram os efeitos especiais, sem aparente disciplina, no qual a luz recebeu um tratamento superficial e "espetaculoso", oferece ao seu público uma visualidade particular, ainda que inconsistente de um ponto de vista artístico-poético.

Essa abordagem incorpora à aplicação da luz na obra artística a compreensão de componentes intravisíveis. A interação entre visibilidade e visualidade revela uma categoria intravisivel presente nos pressupostos estético-poéticos alocados no interior de uma obra, por exemplo, o acontecimento espetacular, e que permaneceriam desconhecidos (in-visíveís) numa hipotética exclusiva aplicação de visibilidade.

Como já foi dito, a resposta do iluminador às atmosferas presentes na ideia primeva de cena inclui aspectos artísticos, exigindo a aplicação de conceitos ligados 
ao discurso visual, como cor, textura, forma, intensidade, ritmo, movimento, equilíbrio, força, entre outros.

Tais procedimentos podem libertar o artista do acaso, da cópia, dos efeitos mirabolantes injustificados, criando sua própria abordagem crítica do espetáculo, na contribuição do seu design para a cena, sem se tornar um inventor, a cada espetáculo. A ciência necessita dos inventores, mas o teatro não pode depender da invenção de um novo aparato a cada espetáculo. Sua opinião sobre a visibilidade e a visualidade que interagem na cena pode dar ao iluminador a autonomia necessária para posicioná-lo como um artista, cujo trabalho tem um papel decisivo no contexto. A consequência disso deve ser uma elaboração cênico-crítica da visualidade inscrita na ideia que originou um espetáculo, incluindo a proposição do diretor, assim como dos demais artistas que elaboram a práxis cênica. Tal elaboração cênico-crítica é promovida pela consulta a fontes primárias (dramaturgia, roteiros) e secundárias, que podem inserir na pesquisa uma extensa ramificação provocada pelas questões culturais indicadas nas fontes primárias, sugerindo contatos com a ciência, a filosofia e as artes. O iluminador pode, portanto, compreender que seu trabalho inclui a natureza de uma pesquisa especializada, permitindo registro e avaliação.

Quando uma ideia é corporificada na cena pela iniciativa de um diretor ao serem estabelecidas relações específicas entre ele e o iluminador, novas variáveis ingressam no processo. O iluminador deve incorporar flexibilidade à compreensão das dificuldades apresentadas por um ou outro artista, no que se refere às especificidades do discurso visual. Com tudo isso, fica compreendido que a interpretação particular de cada iluminador da visualidade proposta pelo elemento provocador do espetáculo, pela ideia inicial da qual ele se origina, determina a assertiva visual que será compartilhada com o espectador ou, a visualidade da práxis cênica. Por conseguinte, visibilidade e visualidade estão indicadas desde o momento no qual um autor começa a elaborar suas ideias, mas só se efetivam na cena através da contribuição da luz.

Os compromissos da cena com a visualidade há muito despertaram o interesse de artistas e teóricos importantes. Escrever sobre tais compromissos, portanto, é seguir uma trilha já iniciada por Sebastiano Serlio (1475-1554), Nicola Sabbattini (1574-1654) e Joseph Furttenbach (1591-1667) e compilada por Hewitt (1958). Como se pode constatar, trata-se de um antigo interesse demonstrado por autores motivados pela raiz científica do olhar que gerou a Renascença italiana.

Depois da Renascença, o mais importante passo da ciência para as relações do homem com a luz pode ser creditado à introdução da luz elétrica, em finais do 
século XIX. Já no início do século seguinte, o trabalho de Louis Hartmann² permite observar a repercussão de tal avanço, no teatro. Ele publicou, em 1930, Iluminação para o teatro: um manual do sistema de controle de luz para o palco (Theatre lighting: a manual of the stage switchboard). Hartmann trabalhou como eletricista-chefe (ou expert em luz) nos espetáculos produzidos e/ou dirigidos por David Belasco ${ }^{3}$ (18531931), nas primeiras décadas do século XX, nos EUA, e inaugurou a trilha da literatura técnica moderna acerca da luz para a cena.

Hartmann integra, então, o extenso conjunto de pesquisadores do século XX que abordaram questões de natureza tecnológica referentes à aplicação da luz no teatro, e o seu livro resulta de exaustiva pesquisa voltada para os espetáculos de Belasco. Tal legado tem repercussão pouco significativa no ambiente acadêmico brasileiro. Em geral, a literatura técnica sobre a luz teatral tem seu valor relativizado cada vez mais rapidamente devido ao furor na busca por novos efeitos e, por conseguinte, o aparecimento frequente de "novidades".

A hegemonia dos efeitos pode priorizar o aparato, repetindo sucessivamente resultados que se transformam em fórmulas. Se no processo de redação do presente trabalho os moving lights ${ }^{4}$ e os painéis de LED $^{5}$ são os nomes em voga, um novo instrumento ou técnica logo se tornará o sonho de consumo. A incessante busca pelo efeito que "está se usando muito" vem lançando certos instrumentos, acessórios e sistemas de controle reconhecidos oportunamente como grande e novíssima solução, no campo do obsoleto.

Louis Hartmann deixou contribuições que sobrevivem até hoje, como a primeira gelatina criada especificamente para um designer. Ele solicitou a produção da gelatina Bastard Amber (Roscogel \#O2), desenvolvida pela Rosco, depois de um achado casual. O próprio nome da cor nasceu de um comentário de David Belasco. ${ }^{6}$ Ainda que a sutileza cromática do filtro bastard-amber não seja vista com frequência em projetos corriqueiros, ele ainda se encontra à disposição e pode ser muito importante, quando não se procura a saturação acentuadamente óbvia. Depois de vinte e oito anos trabalhando juntos, Belasco escreveu no prefácio do

2 Dados biográficos de Hartmann não foram encontrados, constando aqui os registros da sua relação profissional com David Belasco.

3 Diretor e produtor norte-americano que trabalhou no teatro entre os anos de 1884 e 1930.

4 Os moving lights são instrumentos automatizados, que atendem a comandos de um programa de computador, com flexibilidade para mudanças de cor, texturas e movimento. Em muitas situações são chamados de "múvi".

5 Ou: light-emiting diode (diodo que emite luz). O diodo é um componente eletrônico que permite um fluxo elétrico em apenas uma direção.

6 Ver em: <http://www.rosco.com/spectrum/index.php/2012/o1/spectrum-wavelengths-designer-series-louis-hartmann/>. Acesso em: 15 maio 2012. 
livro de Hartmann: "O Sr. Hartmann é um expert em luz, em fazer sombras e colorir, um artista que pinta com fachos de luz e brilhos difusos ao invés de pigmentos e pincéis".7 (BELASCO, 1970, p. V, grifo e tradução nossos)

É importante assinalar que o próprio David Belasco publicou um livro sobre sua experiência teatral. ${ }^{8}$ A primeira edição ocorreu em 1919 e sublinha sua preocupação com a luz. A parceria desenvolvida por três décadas entre ele e Hartmann promoveu etapas importantes nas reflexões em torno do binômio luz-cena. Isso faz do trabalho de Hartmann um documento relevante, não apenas para a compreensão do teatro dos EUA, mas também fornece uma dentre as primeiras teorizações modernas da montagem teatral, incluindo a luz como um dos seus aspectos determinantes. O depoimento posterior de Belasco, no seu próprio livro, delineia a relevância da parceria:

Chega o momento de considerar aquele que é o mais importante fator de uma montagem, a luz das cenas. Discuto a peça detalhadamente com meu eletricista, usando o mesmo método que segui para trabalhar com o cenógrafo. ${ }^{9}$ (BELASCO, 1919, p. 55 , tradução nossa)

O seu processo incluía exaustiva pesquisa referente à dramaturgia, à cenografia e à luz:

As luzes estão para o drama como as palavras para uma canção. Nenhum outro fator de uma montagem é tão eficiente para comunicar seus climas e sentimentos. Elas são tão essenciais para a arte dramática como o sangue para a vida. Atribuo a maior parte do meu sucesso no teatro ao meu sentimento para as cores, traduzido em efeitos de luz. ${ }^{10}$ (BELASCO, 1919, p. 55, tradução nossa)

O termo "efeito" deve ser destacado. Sua questionável compreensão proliferou durante todo o século XX e ainda parece presente, mesmo depois de Jean

7 "Mr. Hartmann is an expert in lights, shading and coloring, an artist who paints with light-beams and diffused glows instead of pigments and brushes."

8 Livro The theatre through its stage door, de 1919.

9 "It is time now to begin to consider what to me is the all-important factor in a dramatic production - the lighting of the scenes. With my electrician I again go over the play in detail, very much according to the method I have previously followed with my scenic artist."

10 "Lights are to drama what music is to the lyrics of a song. No other factor that enters into the production of a play is so effective in conveying its moods and feeling. They are as essential to every work of dramatic art as blood is to life. The greatest part of my success in the theatre I attribute to my feeling for colors, translated into effects of light." 
Rosenthal haver chamado a atenção para sua aplicação, já na década de setenta do mesmo século:

\begin{abstract}
A luz afeta tudo o que toca: o modo como vemos, o que vemos, como nos sentimos sobre isso, e como ouvimos aquilo que estamos escutando. | 'Afeta' [affect] é a palavra chave. Mude o 'a' para um 'e' [effect], e você terá efeitos de iluminação. Os efeitos devem ser tratados com todo o cuidado e usados com a raridade de fogos de artifício. $O$ trabalho mais bem-sucedido e brilhante de um lighting designer é usualmente, o menos notado. ${ }^{11}$ (ROSENTHAL; WERTENBAKER, 1972, p. 3, grifo e tradução nossos)
\end{abstract}

O uso dos efeitos tem grande relevância no discurso visual de um espetáculo. A cena é o momento do processo onde eles são efetivamente testados e aplicados. Somente observando seu resultado na relação com o público pode-se avaliar sua eficiência. Contudo, é possível localizar o equívoco de alguém que desconsidera a sutileza e transforma a luz para a cena numa sucessão descontrolada de efeitos. Conceber um projeto de luz para a cena pode incluir a radicalidade de imagens visuais nas quais a mencionada sutileza é índice determinante. Num movimento contrário à assertiva de Rosenthal, pode haver espetáculos nos quais todas as providências são tomadas para que a luz seja sempre um destaque, um efeito. É compreensível que isso aconteça, se o iluminador mantiver sua "luz" no domínio do senso comum, transformando a cena em um desmedido vai e vem de cores e padrões gráficos. Daí, a fumaça (ou neblina, a umidificação do ar) transforma-se em componente primeiro da luz "espetaculosa".

Louis Hartmann teve como incentivador o professor na Universidade de Yale, Stanley McCandless (1897-1967), que escreveria em 1932 um livro aclamado por estudiosos norte-americanos, Um método para a luz no palco (A method of lighting the stage). Importante dizer que McCandless foi professor de Jean Rosenthal, já citada, na Universidade de Yale, nos anos de 1930.

Antes do aparecimento do trabalho de Hartmann, na década de 1930, a transição entre os séculos XIX e XX trouxe dois artistas investigadores responsáveis por provocações decisivas para o teatro, a partir de então. Trata-se dos já citados Adolphe Appia, cenógrafo e autor suíço e Gordon Craig, cenógrafo inglês, cujas

\footnotetext{
11 "The lighting of it affects everything light falls upon: how we see what we see, how we feel about it, and how you hear what you are hearing. | "Affect" is the key word. Change the "a" to an "e" and you get lighting effects. Effects should be handled with all care and used with the rarity of fireworks. The most successful and brilliant work of a lighting designer does it usually least noticeable."
} 
reflexões e elaborações sobre a contribuição da luz para o espetáculo determinaram passos importantes para o pensamento sistematizado acerca da luz na cena. Os trabalhos de Appia, como exemplo, devem ser observados nas suas devidas proporções, pois não se pode dizer que o teatro estava morto, antes da publicação do seu livro A obra de arte viva (L'ouevre d'art vivant), em $1921 .^{12}$

Deve-se reconhecer o papel de visionários desempenhado por ambos, Appia e Craig, sem perder de vista uma geração de artistas, como os exemplos de Belasco e Hartmann, que alcançaram relevância no seu próprio tempo, sistematizando a montagem teatral de sua época, e contribuindo para a qualidade técnica e artística do teatro profissional moderno.

É importante destacar aqui a importância da interação entre a práxis cênica e a tecnologia e levar em conta o acolhimento de processos tecnológicos, inclusive aqueles oriundos de outras áreas do conhecimento que assumem função determinante na montagem teatral de cada período. No entanto, motivado pelo interesse na mencionada qualidade artística, o presente trabalho evita concentrar-se na descrição dos aparatos, assim como das suas possibilidades técnicas, ou ainda na suposta orientação de uso dos mesmos. Quaisquer compêndios cujo objetivo seja a apresentação de aparatos, de tecnologia, devem ser produzidos com a clareza da sua função de registro histórico. Caso contrário, podem redundar cartilhas obsoletas mesmo antes de serem concluídas, pois não se pode esquecer a progressiva rapidez dos avanços tecnológicos.

Além disso, a sustentação de fórmulas destinadas à elaboração da luz na cena pode resultar numa consideração parcial que acabará por acentuar a "visibilidade", submetendo a luz dos espetáculos às características técnicas dos espaços (teatros), dos instrumentos, acessórios e sistemas de controle. Isso promoverá terreno para a hegemonia dos efeitos que acabam por se repetir, passando de um evento a outro. Talvez fosse melhor identificar tais características e avaliar sua aplicação em cada contexto ou espetáculo, considerando-se as questões estéticas em jogo.

Por outro lado, pesquisadores interessados nas questões de natureza estética não devem interpretar a documentação técnica como um desprestígio às contribuições artísticas da luz para a cena. O exagerado receio pode originar preconceito no que se refere a tal categoria de trabalhos, considerando-os ameaça ou aspecto negativo para a cultura da luz no teatro. Afinal, ainda que seja recomendada cautela na leitura de trabalhos de tal natureza, considerando o momento no qual foram escritos, a precisão e até as discutíveis traduções, cabe lembrar que a docu-

12 Sua obra será abordada adiante, no capítulo "A luz e a cena não realista". 
mentação técnica tem papel importante como registro de etapas e processos. Em qualquer atividade humana, há a possibilidade do uso da técnica, para fundamentação, controle e eficiência. O artista pode aplicar, em muitos casos, procedimentos técnicos, incluindo o planejamento. Mesmo que pareça óbvio, deve-se lembrar que a preocupação com pressupostos estéticos de uma obra não exclui o uso de informação técnica e tecnológica. Afinal, quando se trata de contribuições da luz, há um grande elenco de possibilidades ligadas a um conhecimento já produzido, que pode indicar soluções.

É importante sublinhar a dificuldade em se traduzir documentos da literatura técnica, principalmente manuais de equipamentos. Documentos em língua estrangeira que tratam das relações entre a luz e a cena geralmente se referem a um ambiente muito específico. A atividade de traduzir exige familiaridade com o universo no qual os textos se originaram, para evitar resultados superficiais e/ ou suposições equivocadas que podem comprometer a seriedade das iniciativas, reduzindo seu valor como fontes de estudo. Por outro lado, incorporar de modo indiscriminado expressões em língua estrangeira pode gerar muitos equívocos.

O estudo das habilidades e competências que devem ser incorporadas pelo designer no desenvolvimento de uma carreira no campo do conhecimento artístico aqui abordado pode apresentar certos riscos. Deixar a confiança exclusiva em procedimentos de natureza prática, por vezes em práticas equivocadas e/ou em uma acentuação desmedida da intuição "genial", nortear desse modo uma atividade que incorpora instâncias diversificadas do conhecimento, desde a física até os estudos das artes visuais, assim como da filosofia, da dramaturgia e da história pode resultar em superficialidade de tratamento ou qualidade alcançada ao acaso.

Precisam ser destacados autores que, trabalhando no campo da História do Teatro, trataram as relações entre a luz e o espetáculo na sua condição de aspecto importante para a compreensão das artes cênicas. Dentre eles, destacam-se: Alois Maria Nagler (1907-1993), cuja pesquisa da história do teatro foi decisiva para o estudo aqui empreendido, principalmente quando ele menciona diversificados documentos referentes à atuação da luz, Phyllis Hartnoll (1906-1997), John Ramsay Allardyce Nicoll (1894-1976) e Gösta Mauritz Bergman (1905-1975), cujo trabalho aborda particularmente a atuação da luz na cena.

Deve ser afastada a expectativa de encontrar no trabalho em curso mais uma História da Luz Teatral. Sublinhando a relevância de pesquisas operadas nesse caminho deve-se considerar que escrever agora uma abordagem histórica do tema exigiria um estudo capaz de questionar ou ampliar o alcance do trabalho de especialistas, por exemplo, Gösta Mauritz Bergman (1977). Fica também descartada a 
redação de uma listagem de aparatos - instrumentos, acessórios e sistemas de controle - usados nos espetáculos ao longo da história.

\section{A GÊNESE DA CENA E A VISUALIDADE}

Sem a atenção que o problema exige, pareceria óbvio escrever um trabalho acadêmico acerca da necessidade da luz para o teatro. Afinal, como se repetiu incontáveis vezes, a palavra teatro deriva do verbo théa - ver, em grego, relacionado ao substantivo theatron [ $\theta \varepsilon \dot{\varepsilon} \alpha \tau \rho v$ ], ou lugar de onde se vê ou para ver. Ainda se pode considerar o termo theaomai $[\theta \varepsilon \alpha ́$ o $\mu \alpha 1]$, ver/observar. Num processo associativo, pode-se compreender que o termo theatron se refere ao lugar no qual os espectadores se acomodavam; é justamente onde eles se posicionavam para assistir a rituais, tragédias, comédias, fazendo do teatro um tempo/templo da visão.

Se o objetivo é tornar a cena visível, deve-se, portanto, projetar luz sobre ela. Devem ser evitados obstáculos entre a fonte de luz e a cena, assim como entre a cena e o observador. Já se encontram aqui algumas variáveis. A mais importante exige que a luz apresente brilho capaz de alcançar a cena, para refletir em direção ao observador. Seria possível observar inúmeras variáveis envolvidas na relação entre luz e cena, discutindo as características dos instrumentos, acessórios e sistemas de controle, associando-os à capacidade reflexiva dos materiais aplicados na cena, incluindo o dispositivo cenográfico, os figurinos, a maquilagem, a densidade do ar, entre outros.

As relações entre diversas variáveis oferecem ao designer um amplo espectro de escolhas, permitindo a definição de imagens que serão criadas na cena e estabelecendo diferenças entre tornar visível e construir visualidade através de imagens cênicas. A visualidade pode ser avaliada em seus aspectos técnicos e estéticos, que são associados às imagens cênicas através do trabalho de um designer.

Ao tratar de problemas referentes à direção e à edição de textos de Samuel Beckett (1906-1989), Stanley E. Gontarski (1995, p. 10, grifo e tradução nossos) relata: "Tendo trabalhado em estreita colaboração com Anthony Page no Royal Court Theatre de 1973 na produção de Not I e tendo dirigido-o em 1975 no Teatro d'Orsay, Beckett permaneceu em silêncio ambivalente sobre a imagem visual final da peça." ${ }^{3}$

13 "Having worked closely with Anthony Page on the 1973 Royal Court Theatre production of Not I and having directed it himself in 1975 at the Theatre d'Orsay, Beckett still remained ambivalent about the final visual image of the play." 
A ambivalência de Beckett, no que se refere à imagem visual final da peça, tratando da personagem Auditor, designa a qualidade de "problema visual" para o posicionamento (da personagem) em cena. Ele mesmo descartou o Auditor em montagens que dirigiu, sem nunca haver incluído no corpo do próprio texto tal solução, mas sugeriu tal caminho em correspondência com diretores. Há no pequeno trecho citado um detalhe que merece atenção, quando Gontarski (1995) menciona a "imagem visual" que, aparecendo no final do texto, deixa de ser criada no espaço espetacular. Isso reforça a abordagem da dramaturgia como um problema visual, pré-cênico, e aponta para um estudo específico da cena, recortado por tal viés. Ou seja, qual o papel das imagens visuais, materiais e arbitrárias na cena? Parece óbvio que não há resposta exclusiva para tal questão. No entanto, reconhecendo a visualidade já presente no estado pré-cênico, ${ }^{14}$ o designer pode definir a visibilidade para alcançar a assertiva visual que projeta para a cena.

A expressão visual da práxis cênica inclui cada imagem elaborada, assim como a sucessão de imagens que instalam visualmente a espetacularidade. Pode ser arriscado tomar decisões nesse caminho contando puramente com o acaso ou com a "genialidade" de um diretor ou iluminador. Cada uma das imagens que constituem a cena pode ser encarada como um problema a ser estudado. É possível reconhecer que há critérios para tal procedimento. Quando se identifica a visualidade inscrita na dramaturgia, ${ }^{15}$ cria-se um ponto de vista, permitindo que seja avaliada sua repercussão na cena. Beckett deixou uma brecha no texto, quando se trata do Auditor, e cada diretor tomará sua própria decisão.

A percepção visual atua como um aspecto determinante da relação entre o observador e o espetáculo, envolvendo níveis estéticos e poéticos. Desde metáforas que apareçam no texto até o conjunto de tudo aquilo que é percebido visualmente, na cena, pode ser objeto de estudo do iluminador.

Em Seis propostas para próximo milênio: lições americanas (Lezioni americane: sei proposte per il prossimo millennio), Italo Calvino (1923-1985) expressa uma produtiva relação entre imagens e texto. O livro resultou de um conjunto de cinco conferências, escritas a partir de um convite da Harvard University, em 1984; o evento nunca ocorreu, devido ao falecimento do autor antes da sua realização, até mesmo sem que ele concluísse a sexta e última conferência do projeto. Na quarta conferência, Visibilidade, Calvino indica caminhos para a compreen-

\footnotetext{
14 Todo procedimento que ocorre antes do espetáculo propriamente dito, o texto em si, um ensaio, e assim por diante.

15 Como exemplo; lembre-se que o material do qual se parte para construir a práxis cênica pode ser muito diversificado.
} 
são das imagens como provocadoras da sua própria obra, processo no qual pode ser identificada significativa familiaridade com a abordagem em andamento. É importante, contudo, ressaltar que Calvino (1998) aplica o termo visibilidade de modo diferenciado daquele que a presente abordagem propõe, ou seja: sem a diferenciação estratégica aqui incorporada ao termo visualidade. De todo modo, é relevante observar que Calvino (1998, p. 104) estabelece a importância das imagens para a construção poética: "Quando comecei a escrever histórias fantásticas, ainda não me colocava problemas teóricos; a única coisa de que eu estava seguro era que na origem de um de meus contos havia uma imagem visual".

Ele considerava muito importante a relação com as imagens, não somente para o artista, mas também para o ser humano.

[...] estamos correndo o perigo de perder a faculdade humana fundamental: a capacidade de pôr em foco visões de olhos fechados, de fazer brotar cores e formas de um alinhamento de caracteres alfabéticos negros sobre uma página branca, de pensar por imagens. (CALVINO, 1998, p. 107-108, grifo do autor)

Seu interesse pelas imagens em muito transcendem a mera visibilidade física, remetendo o leitor a um intrigante ambiente no qual as imagens atuam como agentes provocadores da sua narrativa. Elas constituem um pensamento visual que a alimenta e move:

[...] o poeta deve imaginar visualmente tanto o que seu personagem vê quanto aquilo que acredita ver [...] assim como deve imaginar o conteúdo visual das metáforas de que se serve precisamente para facilitar essa evocação visiva. O que Dante está procurando definir será, portanto, o papel da imaginação na Divina Comédia, e mais precisamente a parte visual de sua fantasia, que precede ou acompanha a imaginação verbal. (CALVINO, 1998, p. 99)

Referindo-se a Dante, Calvino (1998) demonstra como a poesia permite interações com imagens mentais, que repercutem e acompanham as imagens verbais na elaboração do texto propriamente dito. Incorporar imagens é um desafio para aquele que elabora a dramaturgia ou outro elemento provocador da práxis cênica. O iluminador, esse não tem escolha: sua função o obriga a criar imagens, mesmo que elas não precisem representar uma invenção "absoluta”, saída de lugar nenhum. É possível estabelecer contatos com o mencionado elemento "provocador". Calvino (1998) distingue dois processos imaginativos, tanto o que parte da 
palavra para chegar à imagem "visiva", quanto o que parte da imagem para chegar à palavra. Quando lê um romance ou uma narração jornalística, o leitor parte da palavra para ver a cena acontecendo diante dos seus olhos, mesmo em fragmentos ou detalhes.

Calvino (1998) acentua a relação entre a capacidade do texto de provocar as imagens e a do leitor de criar imagens mentais, cuja força pode lembrar uma projeção cinematográfica. As imagens cênicas são corporificadas pela presença dos agentes - animados ou inanimados - que compõem a imagem elaborada ou provocada desde a primeira ideia de cena. Ainda que isso não represente, necessariamente, uma novidade, deve-se acentuar que a imagem cênica somente se revelará com a contribuição da luz, estabelecendo relações com processos imaginativos engendrados pelo observador.

A cena pode, então, se configurar como um discurso poético-visual que incorpora a flexibilidade na sua relação com o observador. O termo discurso é aqui compreendido como sistematização de ideias, práticas e pensamentos - no caso, visuais - desvinculando-se das abordagens já exaustivamente aplicadas e questionadas de leitura da imagem. Devem ser evitadas ligações com tentativas, surgidas na segunda metade do século passado, de reduzir a relação do ser humano com as imagens, enclausurando o processo em diferentes molduras do pensamento de cada período. Reduzir a imagem a algo que deve ser "lido" inclui a imposição de limites oriundos da normalização textual, que considera um texto o resultado da organização de pensamentos em palavras, regulada pela gramática e por ideologias.

Cabe lembrar Roland Barthes (2004), quando, no seu texto Aula, ${ }^{16}$ se refere à linguagem como um lugar fechado e à língua como uma relação de servidão e poder. Barthes (2004) aponta como saída a trapaça salutar com a língua, combatendo tal servidão através da possibilidade de jogar, que ele absorve do teatro. Indicando representação e interpretação, o ato teatral de jogar (jouer) propõe uma subversão da língua, cujo poder normativo pode encarcerar o discurso. O jogo teatral inclui no seu discurso instâncias poético-visuais que abrem possibilidades multirreferenciais para questionar as limitações dos papéis do espectador, considerando aquele com quem se compartilha a cena um cocriador de imagens. Na cena, a imagem pode atuar como provocação, afastando-se de qualquer enquadramento que pretenda tornar "legíveis" seus elementos constitutivos. A referência a conceitos, como forma, textura e cor, assim como a derivações que incluem

16 Aula inaugural no Colégio de França, proferida em 7 jan. 1977. 
elementos da natureza própria da imagem, por exemplo, equilíbrio e força, objetiva acentuar a apreensão de tais elementos como componentes da provocação dirigida ao observador que, instigado pela visualidade da cena, assume o papel de criador de imagens (suas próprias imagens).

Ao incorporar a visão como aspecto intrínseco da sua efetivação, o teatro grego já investia na elaboração de imagens em movimento, de natureza muito semelhante àquelas que Jean-Jacques Roubine (2003, p. 29, grifo nosso) menciona: "Ora, na ótica de Aristóteles, sua finalidade [a do teatro] é, como vimos, a catarse, que só pode operar se o espectador acaba por confundir a imagem e seu modelo". o "modelo" em questão refere-se ao amplo conceito de "natureza", como objeto a ser mimetizado pela imagem criada na cena. Roubine já identifica em Aristóteles a imagem como um inexorável aspecto da cena. Diferente daquela que ele identifica como o corpo-imagem do cinema:

No cinema, o corpo estabelece uma forma completamente diferente [daquela que se dá no teatro] de relação com o espectador. Sendo uma imagem, ele está fisicamente 'ausente', por mais forte que possa ser a sua presença na tela. Engano, ilusão... Pois este corpo, se é ausente, irreal, é ao mesmo tempo valorizado, exaltado, pelos efeitos de filmagem e edição. Paradoxo da 'presença-ausência', aqui levado à sua máxima tensão. (ROUBINE, 1982a, p. 39)

Antes, o mesmo autor já havia reconhecido: “[...] o corpo não é por natureza, teatral. Ele precisa aprender a se movimentar, e mesmo a 'estar', no espaço artificial que é o palco". (ROUBINE, 1982a, p. 32) Importante observar que o termo artificial não apresenta qualificação negativa e, sim, reconhecimento da natureza do teatro. Isso equivale a dizer que, mesmo algo posto em cena para "parecer natural", só alcançará tal objetivo, se artificializado de modo preciso. Portanto, a imagem criada no contexto espetacular, qualquer que seja o modelo ou o estilo, será sempre um produto artificialmente criado por um artista, ou grupo de artistas. Todo elemento constitutivo da imagem deve ser submetido a um tratamento artificial, especialmente elaborado para cada proposição. Nesse conjunto está incluída a luz, pelo menos enquanto a cena mantiver sua raiz grega e oferecer algo para que o espectador perceba visualmente, uma imagem, ou sucessão de imagens, em movimento.

Ainda Roubine (1982b, p. 32):

[...] aquilo que o espaço cênico nos faz ver é uma imagem. [...] em três dimensões, organizada, animada... Descobre-se que 
essa imagem pode ser composta com a mesma arte que um quadro, [...] a organização das cores, o jogo das áreas cheias e vazias, das sombras e luzes, etc.

Ele faz tais considerações, ao tratar do simbolismo no teatro. Tal observação deixa, no entanto, uma questão: em que situação a cena abandona a condição de imagem, desconsiderando a organização das cores, o estudo de área e massa e da interação entre sombra e luz? A cena nunca alcançou tal direito. Enquanto mantiver a condição de objeto artístico, "artificial", não importam estilos ou revoluções, ela ainda será "grega", no sentido de oferecer ao público uma imagem, como diz Roubine (1982b), tridimensional, mas segundo um ordenamento particular, um discurso em movimento; inserida, portanto, no tempo.

Observando o teatro de Gordon Craig, Roubine (1982b, p. 57) afirma:

O 'regente' deve organizar seus cheios e vazios, animá-los, modificá-los pelo recurso à luz. Se o teatro persegue o sonho de ser uma arte sagrada, então a imagem cênica deve ser composta com tanto cuidado quanto um quadro. Mas o teatro é também movimento e mudança, uma vez que a representação não é apenas inscrição em um espaço, [...].

Ainda que concentrado no estudo de um artista, estilo e período, Roubine (1982b) revela nuanças indissociáveis presentes em qualquer manifestação teatral, à parte as qualidades do sagrado. Mesmo um teatro cruamente profano estará submetido e exige a criação da "imagem cênica", de composições em movimento, não apenas uma, mas uma sucessão finita, elaborada para cada espetáculo, em parceria com a luz. Incorpora-se neste trabalho o objetivo de identificar tal processo, em diversos momentos representativos da práxis cênica, na expectativa de reconhecer o papel da luz como problema que demanda estudos particulares, numa relação direta com o discurso visual provocador de cada um dos momentos da cultura teatral.

Tal imagem cênica difere da abordagem moderna de imagem, exaustivamente discutida como uma imagem elaborada pela tecnologia que possibilitou o seu registro, sua manipulação e reprodução. Se a imagem material, plástica, pode ser remontada à arte rupestre, datada do Paleolítico Superior (40.0oo a.c.), e alcançou a sofisticação pré-capitalista da pintura a óleo, transformando-se em objeto portável e negociável, na imagem cênica é possível reconhecer a ingenuidade crua daquelas inscritas no contexto de quatro dimensões (incluindo sua efetivação temporal) dos rituais testemunhados pelo mesmo artista do período 
rupestre. Ela ainda pode ser efetivada pela presença de um ser humano (artista), que busca a fisicalização artificial de um objeto (ou modelo) ausente.

O artista que pintou as imagens das cavernas em Lascaux, na França, há mais de 15 mil anos, poderia estar próximo da ordem antropológica das imagens performativas. Ele selecionava um conjunto de materiais e instrumentos para trabalhar no suporte escolhido, as paredes das cavernas. Podem ter sido necessários andaimes e luz artificial. Considerando a instabilidade da luz produzida pela suscetibilidade das fontes às correntes de ar, pode-se imaginar a mobilidade das imagens, mesmo enquanto eram pintadas. O pintor deveria selecionar as intervenções (traços, linhas) que materializariam a imagem que lhe vinha à mente. Se o pintor estava acompanhado por alguém que assumia o papel de observador da sua habilidade e competência para gravar a imagem, sua atividade ganhava uma qualidade quasi-espetacular, podendo contemplar aspirações das mais recentes revoluções performáticas, incluindo a novíssima arte da ação, sem "personagem", derivada das artes visuais.

Na caverna citada, portanto, alguém (artista, performer) era contemplado por outro (um espectador/observador) enquanto efetivava uma ação, sob luz artificial, especificamente instalada para tal fim. Tratava-se de uma espécie de fronteira entre a visibilidade promovida pela fonte de luz artificial aplicada para permitir o trabalho do pintor e a visualidade daquele momento de elaboração da imagem que ganha, então, características de performance (visual). A sombra do pintor não deveria incidir sobre a imagem plástica, pictórica, enquanto a mesma estava sendo elaborada, exigindo determinado posicionamento das fontes de luz artificial. O corpo do pintor, em si, era uma imagem que criava a segunda imagem, profundamente enraizada na cultura (suas observações, seus desejos ou sonhos), da qual ele retirou seu modelo. A imagem visual (cênica?) do corpo do pintor desvanesceu-se no tempo, e a imagem plástica, gravada, sobreviveu. A imagem plástica de um animal ainda hoje presente, afirma a efemeridade da outra imagem (cênica, teatral, performática) ausente. Mas isso não deve impedir o estudo desta última, da sua recriação crítica.

Quaisquer quebras de paradigmas espetaculares, por mais revolucionários que sejam, quando põem em cena um ser humano, estão elaborando imagens que contam com a presença de um corpo fisicalizador do desejo de presentar-se (ou "presentificar-se") em cena. Afirma-se, portanto, a práxis cênica, como interação de imagens: verbais, sonoras, olfativas, mentais, e, também, visuais. A cena como meio que efetiva a imagem total do evento espetacular e, simultaneamente, como fisicalização artificializada do corpo que cria e projeta imagens, desde, e em si mesmo. A qualificação da totalidade das imagens não pressupõe, necessaria- 
mente, unidade. Em tempos nos quais ainda se fala de pós-modernidade, pareceria ingenuidade impor à cena, a unidade das chamadas "grandes narrativas".

\section{A CENA E O ESTUDO DAS IMAGENS}

A discussão iconológica empreendida pelo estudioso alemão Hans Belting (2005) pode contribuir para a abordagem da imagem que norteia esta investigação:

Os papéis que têm sido destinados à imagem, aos meios e ao corpo variam frequentemente, mas sua estreita interação continua ativa até hoje. O medium, a despeito do seu caráter polissêmico e aplicação polivalente, oferece a mais facilitada identificação e, por essa razão, é favorecido pelas teorias contemporâneas. O corpo apresenta-se em seguida, mas é frequentemente e de modo excessivamente purista, impelido contra as atuais tecnologias e considerado seu observador. Impõe-se, portanto, uma nova ênfase aos corpos, como meios vivos, capazes de perceber, lembrar e projetar imagens. O corpo como proprietário e destinatário de imagens, meio administrado como extensões das suas próprias capacidades visuais. Corpos que recebem imagens, percebendo-as, e na condição de media as transmitem para corpos. Com a ajuda de máscaras, tatuagens, roupas e performance, corpos também produzem imagens de si mesmos ou, no caso de atores, imagens que representam outros, caso em que atuam como media no sentido mais pleno e original. Seu monopólio inicial na mediação de imagens nos permite falar de corpo como o arquétipo de todas as media visuais. ${ }^{17}$ (BELTING, 2005, p. 315, tradução nossa)

Em diversificadas instâncias, a assertiva de Belting tangencia o foco do presente trabalho. Importa, contudo, acentuar sua menção ao ator como lugar da tríade por ele cunhada, imagem-meio-corpo. E mesmo que esse ator seja banido

\footnotetext{
17 "The roles that have been assigned to image, medium, and body constantly varied, but their tight interaction continues up to the present day. The medium, despite its polysemantic character and polyvalent use, offers the easiest identification and is for this reason favored by contemporary theories. The body comes next, but it is all too often and all too neatly played out against current technologies and considered as their obverse. It therefore needs a new emphasis on bodies as living media, able to perceive, to remember, and to project images. The body, as owner and addressee of images, administered media as extensions of its own visual capacities. Bodies receive images by perceiving them, while media transmit them to bodies. With the help of masks, tattooing, clothing, and performance, bodies also produce images of themselves or, in the case of actors, images representing others - in which case they act as media in the fullest and most original sense. Their initial monopoly on mediating images allows us to speak of bodies as the archetype of all visual media."
} 
para dar lugar ao agente do teatro performativo, o acontecimento espetacular ainda se efetivará no âmbito desse trinômio. Sua abordagem da iconologia interage com os estudos de William John Thomas Mitchell, comentando aquilo que Mitchell apresenta como imagem, texto, ideologia. Ambos estão em conexão com vários outros que dedicaram, e vêm dedicando esforço na investigação da imagem.

Belting tem sido mencionado como referência para o estudo antropológico da imagem e do termo alemão Bildwissenchaft, cuja tradução já apresenta um problema, podendo-se compreendê-la como "ciência da imagem". O contexto pode incluir vários estudiosos, desde Erwin Panofsky (1892-1968), considerando-se suas proposições acerca da Iconologia. Uma importante introdução ao estudo do mencionado contexto foi oferecida por Paulo Knauss, no seu abrangente artigo, publicado em dezembro de 2008, "Aproximações disciplinares: história, arte, imagem". As discussões e ramificações norte-americanas, inglesas e também alemãs, contemplam um significativo campo de estudos que inclui propostas de investigação da imagem, não apenas como um aspecto a ser abordado pela história da arte, mas também como campo específico de estudo.

No contexto do presente trabalho, a imagem corporifica na cena o desejo do artista de conectar-se com o outro que recria as imagens a ele oferecidas. Se há um corpo, incluem-se visão e mente. Um artista - que pode ser um dramaturgo - ausente do ponto de vista físico, elaborou um construto que transitou desde a condição de imagem mental elaborada pelo autor, até a corporificação ou, a imagem visual presente na cena. Na sua mais direta e operacional configuração, a cena propõe um jogo que exige a presença do corpo do ator, meio principal de elaboração da imagem cênica, e o corpo do observador, que a reelabora. Meios vivos, ativos.

O trinômio proposto por Belting liberta a práxis cênica da clausura de determinadas teorias "revolucionárias" que, como tal, vêm acompanhadas de prazo de validade, sendo desconstruídas na próxima revolução. Um novíssimo performer que executa uma "ação" (desprovida da adjetivação "cênica") para alguém que aceitou o papel do fruidor "não performer", estará se efetivando como imagem-meio-corpo, assim como esteve um ator ou atriz do mais rigoroso realismo, do melodrama, da farsa medieval, da tragédia grega, e assim por diante. A menos que se invente uma "ação" ou categoria de performatividade que remova deliberadamente a expressão-comunicação-percepção visual, o comentado trinômio estará sempre presente.

Ainda que tal processo possa configurar um intricado contexto epistêmico, observando-o cuidadosamente pode-se, por outro lado, apreender sua simplicidade. Uma situação que se instale na interação do ator com o outro, o espectador 
ou o "não ator" da situação, pode ser efetivada, literalmente, com a presença de apenas um representante de cada categoria, numa relação direta. O corpo de um ator que interage com o corpo do "não ator" pode prescindir de qualquer elemento físico externo, à parte o ar que os manterá vivos, e a luz. O corpo nu do ator, sob a luz natural, sem a intervenção de quaisquer mecanismos de controle ou proteção, disposto num espaço preexistente, também sem nenhuma interferência ou artificialização, é perfeitamente capaz de criar presença artística no mencionado acontecimento - para não dizer espetáculo - ou sucessão de imagens.

E o sujeito " $\mathrm{A}$ " do acontecimento, o ator - ou performer - pode até prescindir de um modelo, de uma personagem, e configurar a si mesmo como estímulo e meio. Assim, ele estará projetando sua própria imagem em um novo nível de expressão, na medida em que ela estará incorporada a um acontecimento de qualidade artificial - ou artística (para evitar, nesse momento, termos como teatro e cena). Ou seja: mesmo com a ausência de personagens, conflito ou cena, mesmo que a única vontade presente no acontecimento seja a do ator - ou do performer que o nega ao desejar ele mesmo estar diante de alguém, o outro que aceitou o papel de sujeito "B", um observador-espectador-“criador"-fruidor, "não ator", cuja função é compartilhar com "A" o acontecimento, ali se efetivará o trinômio imagem-meio-corpo.

Além disso, pode-se até especular acerca da visualidade relacionada à ausência material do corpo do dramaturgo, ou outro criador responsável pela gênese do processo provocador da cena, e mencionar a corporificação da imaginação desse artista, um locus de impossível acesso material e imediato para o observador-espectador-criador-fruidor, "não ator".

A cena se rebelará contra qualquer tentativa de apontar uma autoria isolada ou exclusiva, já que sua natureza compósita impõe interação, equilíbrio - por vezes, ou com frequência - assimétrico, ou seja: os aspectos da cena interagem de modo dinâmico, transversal, ainda que não se perceba racionalmente, até mesmo numa aparente negação provisória, ou momentânea, de um ou mais aspectos, resultando na acentuação pontual de outro(s).

Como exemplo, o corpo nu do ator, mencionado acima, pode não ser considerado, necessariamente, uma simplória exclusão do figurino. Quando se define a ausência de indumentária, elementos externos ou estranhos ao corpo do ator, uma espécie de "não roupa" passa a configurar a escolha deliberada, eleita para transformar a pele do ator em figurino único e indispensável, primevo, para aquela entidade, na imagem-cena (ou cena-imagem).

A imagem já foi considerada anulação do corpo em interpretações de Narciso e dos estudos de Platão, pois pensada como representação, um segundo que devasta 
a potencialidade do primeiro que o origina, "descorporificando-o". Como uma sombra que esconde, mente e deforma, tornando bidimensional, "chapando", destruindo a profundidade da experiência, o conhecimento. Ainda que se possa

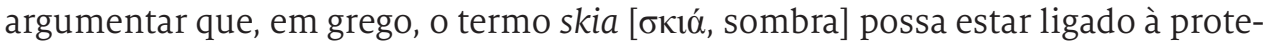
ção, ao abrigo. Além disso, não seria surpresa testemunhar a desqualificação da imagem, ou a demonização da visão, considerando-as aliadas do cientificismo da modernidade a partir do cartesianismo perspectivista que narra um mundo pensado. Um mundo fitado através da visão monocular calculada, já investigada por Filippo Brunelleschi (1377-1446) e difundida por Leon Baptista Alberti (14041472). Desde o século XV, portanto, lançavam-se bases do pensamento mais tarde incorporado pela filosofia.

O ideal renascentista de permitir ao ser humano a investigação da vida, buscando a compreensão sistemática daquilo que ocorria diante de si e a capacidade de dividir com o outro aquilo que ele pensava ver, representando-o cientificamente, rompia as barreiras do olhar divino medieval. Por outro lado, tal processo parece ter resultado num tiro que saiu pela culatra e gerou a criticada hegemonia da visão cientificista moderna. Num determinado momento, acreditou-se que o cientificismo exacerbado, duro, da modernidade engendrada pelo cogito ergo sum cartesiano tinha a visão como cúmplice maior. Consequentemente, as imagens produzidas pelo ocularcentrismo moderno, de raiz renascentista, eram vistas como provas do crime.

O teatro, no entanto, sempre pode ser desatrelado de tais comprometimentos, quando recupera diariamente (ou a cada noite) a imagem cênica que, como já foi dito, esteve presente desde rituais do Paleolítico. Ao recuperar uma imagem que pode ser simplesmente corporificada no ator, independentemente de qualquer artificio visual, a cena desmembra e multiplica o ator, permitindo-lhe assumir virtualmente o triplo papel sugerido por Belting, imagem, meio e corpo, operando em um complexo artificial de quatro dimensões (considerando a tridimensionalidade espacial e o tempo). Ele é imagem, meio e corpo vivos, simultaneamente, no nível temporal da cena. Ou seja, a imagem cênica que alcança o observador, provocando e interagindo com seu imaginário, tem como meio o corpo do ator. Além disso, mesmo sendo uma categoria de imagem que precede e transcende os limites da técnica moderna, sua flexibilidade permite interações com as imagens tecnológicas, quaisquer que sejam os estágios da tecnologia. E a imagem cênica elaborada no corpo do ator subverte a imagem tecnológica, emprestando-lhe funções diferentes daquelas designadas no seu meio original, novas funções que resultam da interação com o corpo vivo. 
Observando as famílias de imagens propostas por William J. Thomas Mitchell (1986), estudioso norte-americano já mencionado, cujo trabalho é referência para a Cultura Visual, pode-se considerar que a cena se configura como um amálgama de ramificações das "famílias" de imagens, no qual imagens gráficas, ópticas, perceptivas, mentais, verbais, sonoras, juntam-se para criar as semelhanças e dessemelhanças propostas por um espetáculo. Mitchell procura estabelecer um terreno no qual possam transitar as mencionadas famílias de imagens. Ele associa ideia (idein, em grego: forma, padrão) ao verbo ver e acentua que o termo está ligado à imagem visual (eidolon), de uso corrente na óptica antiga e na teoria da percepção. Mitchell (1986) reconhece a prudência da estratégia platônica que distinguia eidos - a realidade suprassensível, constituída de formas, ideias e espécies - de eidolon - a impressão sensível que provê o simulacro - eikon - ou o termo latino phantasma (que se origina no grego phantazo, phantazein, ou tornar visível, e ainda phaeinein, mostrar), ilusão do eidos.

No entanto, ele propõe uma abordagem de maior risco:

Isso envolve a atenção para a maneira como as imagens (e ideias) assumem umas os lugares das outras: a maneira como descrevemos o ato de retratar, imaginamos a atividade imaginação, figuramos a prática da figuração. Esses quadros, imagens e figuras duplicadas [ ] são estratégias para, tanto ceder, quanto resistir à tentação de ver ideias como imagens. ${ }^{18}$ (MITCHELL, 1986, p. 5-6, tradução nossa)

O teatro se refaz sucessivamente na construção intermitente da imagem cênica corporificada no ator. Parece óbvio, mas vale repetir: o gérmen da imagem já estava latente na primeira imagem mental, ou ideia (lembre-se sua origem em idein: forma, padrão, imagem) experimentada pelo dramaturgo. Daí, a noção de pré-cênico. Ainda que determinado momento da história da práxis cênica possa incluir a hegemonia de um ou outro aspecto de sua constituição, negando textos, modos e modelos que o tenham antecedido - incluindo a figura do dramaturgo o acontecimento em si ainda pode estar comprometido com uma primeira ideia (ou imagem mental) que o originou.

Tal processo inclui a articulação de visualidade que gera e está presente na cena. De tal articulação podem tomar parte ilustrações, figuras, estátuas, projeções óticas, aparências, dados sensoriais, sonhos, memórias, ideias, metáforas, narra-

18 "This involves attention to the way in which images (and ideas) double themselves: the way we depict the act of picturing, imagine the activity of imagination, figure the practice of figuration. These doubled pictures, images, and figures [...] are strategies for both giving into and resisting the temptation to see ideas as images." 
ções, descrições, entre outras manifestações da imagem. O que inclui a imagem superfície invocada por Flusser (1985), que pode ser confundida com limitação bidimensional. Elas podem juntar-se, chocar-se, interagindo com o ator e, consequentemente, com o observador. Isso pode envolver diversificados campos de conhecimento, como a psicologia, a epistemologia, a física, a história da arte, a fisiologia, a neurologia, a filosofia e até a crítica, literária e teatral. Tudo isso, como resultado da criação de uma imagem em movimento, radical, a imagem cênica, que não permite - ou resiste - à gravação mecânica, analógica ou digital.

A despeito das críticas que ligam o trabalho de Rudolf Arnheim ao formalismo, vale lembrar sua abordagem da imagem que, engendrada no interior de uma obra, se relaciona, inevitavelmente, tanto com a imprevisibilidade e a flexibilidade do objeto artístico, quanto com a objetividade do contexto no qual está inserida. Discutindo a pintura de Johannes Vermeer (1632-1675), Mulher segurando uma balança (Vrouw met weegschaal, de 1665) Arnheim pondera que as conclusões às quais alguns comentadores podem chegar, relacionando a mulher com a pintura que se vê atrás dela, ${ }^{19}$ levando em conta sua ação de pesar a riqueza, dependem de interações com o entendimento intelectual que relaciona os dois temas (Figura 1).

Arnheim (1994) destaca as elaborações visuais construídas por Vermeer: em primeiro lugar, o artista dispõe a cabeça da mulher imediatamente abaixo da figura do Cristo, indicando familiaridades na cor, na forma ovalada e na proximidade; depois, ele desloca a mulher do centro e ali insere um elemento contundente na organização visual, a moldura da pintura ao fundo, que além do comentado posicionamento, do contraste entre os valores da parede altamente iluminada e da sua própria cor escura, estabelece um ângulo de noventa graus com o limite horizontal da própria moldura, em frente do qual Vermeer colocou, precisamente, a mão da mulher que, como uma extremidade do corpo tem relevante papel visual.

Considere-se o importante papel das extremidades do ser humano, como elementos visuais que promovem a alteridade. Afinal, ainda que se possa criticar a media pela imposição do apelo à imagem elaborada superficialmente em pressupostos sexuais, ao longo da história moderna, não se pode negar a importância visual da genitália, como uma das extremidades do corpo humano, assim como os olhos, os pés e as mãos, elementos de referência para o contato com o outro e com o mundo. A estratégia elaborada por Vermeer corrobora seu interesse em discutir visualmente o contexto intelectual no qual sua pintura transita.

19 Em O juízo final, cuja autoria não se sabe ao certo, Vermeer pode ter usado elementos de várias obras. 
Vale lembrar, quando nos escritos póstumos, Friedrich Nietzsche (2005, p. 16), diz: "Ao conceito corresponde primeiro a imagem, as imagens são pensamentos originais, [...]". No teatro, conceber a imagem como modo primevo de pensar, sugere a aproximação entre as imagens mentais e os artefatos físicos que as corporificam, definindo o corpo do ator como referência para as imagens criadas na cena. O que é a imagem e qual o seu papel, ainda será motivo de disputa entre vários campos do conhecimento, como observa Belting (2005, p. 304, tradução nossa):

A semiologia, para dar um exemplo, não permite que as imagens existam para além do território controlável de símbolos, sinais e comunicação. A teoria da arte teria outras reservas, mas igualmente fortes, sobre qualquer teoria da imagem que ameace o antigo monopólio da arte e seu assunto exclusivo. As ciências, em particular a neurobiologia, examinam a atividade perceptiva do cérebro como um fenômeno de 'representação interna', enquanto a percepção de artefatos geralmente recebe pouca atenção neste contexto. ${ }^{20}$

Seria inconsequência arbitrar tais querelas, pois, a julgar pela dinâmica participação na cultura, as diversas "imagens" parecem se tornar cada vez mais sintomas e traços sociais agudos. Vale encarar sim, provocações, para buscar a compreensão daquilo que a luz pode incorporar ao contexto do espetáculo, na sua condição de conjunto dinâmico de imagens cênicas - em movimento.

E aqui pode ser introduzido um conceito que exige leitura cuidadosa. Trata-se de um processo empreendido pelo iluminador, quando ele cria uma imagem deflagradora para a cena, uma espécie de concentração latente das imagens cênicas, uma imagem-gênese, que precede a cena de modo perene. Como o leitmotiv ${ }^{21}$ na música, ela estará sempre presente no espetáculo, através dos elementos que a constituem. Mesmo que pareça invisível, a imagem-gênese soará constante nas

20 "Semiology, to give one example, does not allow images to exist beyond the controllable territory of signs, signals, and communication. Art theory would have other but equally strong reservations about any image theory that threatens the old monopoly of art and its exclusive subject matter. The sciences - in particular, neurobiology - examine the perception activity of the brain as a phenomenon of 'internal representation', while the perception of artifacts usually receives little attention in this context."

21 Termo alemão. Pode ser compreendido como tema dominante, recorrente ou condutor. Estratégia reconhecida desde o período inicial da ópera, o termo foi cunhado por Friedrich Wilhelm Jähns (1809-1888), em 1871, referindo-se à obra de Carl Maria Friedrich Ernst von Weber (1786-1826), importante compositor de ópera romântica e é mais frequentemente associado a Wagner, a despeito da severa crítica de Adorno (Theodor Ludwig Adorno Wiesengrund, 1870-1941) no seu trabalho Versuch über Wagner (Em busca de Wagner), publicado nos anos cinquenta, do século passado e que aparece nas referências através da tradução inglesa (In search of Wagner, 2005). Vale acentuar que desde o século XX, o leitmotiv é também relacionado à literatura, ao cinema, e ao teatro, manifestando-se também em imagens dominantes que transitam nas obras. 
cores, texturas e formas inscritas na cena. Na qualidade de imagem deflagradora, transitará de modo intermitente na visualidade do espetáculo, sucessivamente corporificada em notas, acordes e harmonia visual, o que não afasta a possibilidade de uma imagem atonal, ${ }^{22}$ como exemplo.

Ou ainda, num exercício desafiador, qual seria a imagem deflagradora da peça Parade, do compositor francês Erik Satie (Éric Alfred Leslie Satie, 1866-1925), considerando-se o choque causado pela obra, no espetáculo realizado no ano de 1917, em Paris? É importante a busca da imagem que agiria como provocação para o pensamento visual daquele espetáculo. Daí, cumplicidade e familiaridade com a obra musical são imperativas. Isso não significa que o iluminador tenha prévio domínio dos diversos aspectos da questão e, sim, que ele reconheça a necessidade de estudos que o qualifiquem para tomar decisões pertinentes.

Ficaria, portanto, questionado o ato simplório de projetar alguma luz sobre o espaço cênico para que o público veja o espetáculo. À pretensa operação físico-química-mecânica de projetar luz sobre o que se deseja mostrar - caracterizada aqui como promoção de visibilidade - impõem-se as ações deliberadas de um artista em busca do ambiente visual de sua obra, ou da criação de sua visualidade. Antes do interesse em expor algo para que o público veja o que está em cena como um contemplador passivo, efetiva-se a criação de imagens que provoquem o observador, levando-o a elaborar visualidades.

Mesmo os resultados mais "brilhantes, coloridos e repletos de movimentação" podem permanecer nos limites da visibilidade estéril no que se refere à natureza estético-poética da práxis cênica, permanecendo aquém de uma proposição artística. Aqui se configura uma armadilha na qual o iluminador pode cair, diante da facilidade em aprender que o público, em geral, deixa-se impressionar pela esterilidade visível na qual podem mergulhar os espetáculos, mesmo aqueles coloridos, brilhantes, repletos de fumaça e graficamente "nervosos". Vale ponderar que a criação da visualidade de um espetáculo incorpora o risco agudo da obra de arte, uma vez que o espectador sempre estará interagindo com o que vê, em trânsito dinâmico com o seu imaginário.

De todo modo, é dado ao iluminador, o direito de confrontar a postura que considera o espectador como alguém que diz impunemente: "estou apenas olhando", com a compreensão do espectador-corpo que, na práxis cênica, compartilha espaço

22 Levem-se em conta as críticas ao conceito de atonalidade, desde a opinião do próprio Albert Schoenberg (18741951), no seu livro Harmonia (Harmonielehre, 1911), que aparece nas referências através da tradução inglesa, Theory of harmony (1978). 
e tempo com o outro corpo, o ator. Tal processo incorpora o amplo leque de aspectos culturais que constituem a visualidade.

Na práxis cênica tal processamento inclui a luz como aspecto determinante da interação com o quadro de referências que repercute as contribuições da luz para a construção da cultura. E a visualidade instalada na cena, através da interação entre os elementos que a constituem, expõe e questiona a visibilidade artisticamente estéril. Afinal, se os procedimentos responsáveis pela produção das "autonomias" que "destruiriam" a unidade de tratamento não forem cuidadosamente investigados, essa unidade pode ser alcançada ao acaso. Isso poderia resultar na negação de uma proposta revolucionária, que findaria atrelada ao antigo desejo de unidade, execrado pelos seus promotores. Ou seja, ainda que o objetivo seja a "desunidade", o acaso e/ou a genialidade podem não ser a solução.

O que se caracteriza aqui como visualidade indica a fisicalização das ideias de um artista ou grupo de artistas, ou seja, o caráter visual de uma obra. Vale comentar o termo caráter, do verbo grego kharakessein, ou gravar; daí deriva kharakter (caráter), que se refere a uma "marca gravada". Suspeita-se, então, que o iluminador tem a liberdade de propor uma marca poética na visualidade de cada acontecimento cênico.

Fica encaminhada uma problematização que observa a natureza estética da práxis cênica, considerando relações com a luz em uma abordagem mais abrangente, ou seja, que sublinha o caráter visual do espetáculo.

Tal abordagem já aparece anunciada por Adolphe Appia, em 1898. Inicialmente, ele faz uma constatação que parece óbvia: “[...] a visibilidade é um importante aspecto de uma montagem: se o público deve assistir à peça, a face do ator deve estar claramente visível."23 (APPIA, 1962, p. 20, tradução nossa) Adiante, ele completa:

Agora, o que, se não a luz, dá essa maravilhosa unidade ao espetáculo que contemplamos cada dia, permitindo-nos viver através de nossos olhos? | Sem essa unidade, seremos capazes de distinguir apenas vagamente o significado das coisas, e nunca a sua expressividade, pois, para que as coisas sejam expressivas, elas devem ter forma, e forma sem luz, só se comunica com o nosso sentido do tato. (APPIA, 1962, p. 46, tradução nossa) ${ }^{24}$

23 "[...] visibility is a major consideration in production; if the audience is to experience the play, the faces of the actors must be clearly seen."

24 "Now what is it if not light that gives that wonderful unity to the spectacle we contemplate each day, allowing us to live through our eyes? Lacking this unity, we should be able to distinguish only dimly the meaning of things, 
Em uma nota de rodapé, Appia esclarece seu enfoque e abre uma trilha que ainda hoje parece pouco discutida, mas que promoveu o suporte para o encaminhamento da compreensão do papel da luz na cena, discutido no presente traba1ho. Ele alerta: "Quando me refiro à luz, é evidente, quero dizer, a atividade luminosa, e não, de usá-la apenas para enxergar."25 (APPIA, 1962, p. 46, tradução nossa)

Levando-se em consideração um estágio que se expande para além da simplória visibilidade mencionada por Appia, para além das meras operações mecânicas usadas no intuito de tornar a cena fisicamente visível, fica identificada a função do iluminador como alguém que contribui para a visualidade da qual a cena está, ou deve ser impregnada. Ao questionar a mera visibilidade, Appia parecia considerar o caráter e a função da luz como uma atitude esteticamente ativa e capaz de construir visualmente uma obra teatral. A busca por tal qualidade representa, no núcleo da presente abordagem, tarefa fundamental e pode, de acordo com as razões mencionadas, indicar diversificadas ramificações estético-filosóficas, de acordo a cada obra e/ou contexto.

Num certo sentido, tanto a decisão mecânica de tornar visível projetando luz, quanto aquela de esconder na escuridão teriam o mesmo resultado destruidor. Além disso, fica uma indagação: uma vez que a presença de um responsável, em particular, pelo comportamento da luz artificial na cena seja muito recente, ${ }^{26}$ como ela era tratada no teatro, até o aparecimento do responsável pela sua incorporação? Já na década de 1970, ainda eram testemunhados processos nos quais a luz ficava a cargo de um eletricista encarregado de fazer "gerais" coloridas, focos e efeitos; era uma espécie de fórmula, que se repetia sem indícios de qualquer preocupação com um possível universo visual ao qual os espetáculos se relacionassem ou aos quais se referissem.

Deve-se sublinhar a honrosa tentativa de Jean-Jacques Roubine de se aproximar do estudo da luz, esboçando a intenção de sistematizá-lo. Ele concentra sua abordagem em diretores e/ou teóricos, tais como André Antoine (1858-1943), Constantin Stanislavski (1863-1938), Antonin Artaud (1896-1948), Adolphe Appia (1862-1928), Gordon Craig (1872-1966), Jean Villar (1912-1971), Bertolt Brecht (18981956), Jerzy Grotowski (1933-1999), Giorgio Strehler (1921-1997), Patrice Chéreau e Peter Brook. Da abordagem de Roubine pode-se extrair uma tentativa de classificar

\footnotetext{
and never their expressiveness; for in order that things be expressive, they must have form, and form without light communicates only to our sense of touch."

25 "By light, I mean the activity of light, not simply 'visibility'."

26 A identificação de um especialista responsável exclusivamente pela luz, em um espetáculo, só aparece na transição entre os séculos XIX e XX.
} 
ou identificar caminhos seguidos pela luz, principalmente depois da luz elétrica. Ele cita ao menos três qualificações: a iluminação atmosférica (do realismo), a "iluminação-cenografia" (como em Appia e Craig), a não figurativa e a simbólica (desde Artaud).

Suas observações podem ser absorvidas como uma provocação positiva, tanto no que se refere à extensa discussão possível em torno de cada um dos mencionados termos ou expressões, quanto pela ausência de menção específica a qualquer iluminador, em suas considerações. A luz é considerada pelo viés da dramaturgia e/ou da direção.

Outra assertiva de Roubine (1982b, p. 31) pode ser destacada. Tratando daquilo que caracteriza como simplicidade, ele afirma: "[...] a iluminação que se assume como puro instrumento da representação, nada mais é do que um meio de tornar um espetáculo visível e legível [...]". Classificações de tal natureza aparecem quando se analisa a luz realista como tentativa exclusiva de tornar a cena visível, iniciativa que Roubine qualifica como "atmosférica". Para tornar um evento visível, no entanto, não há necessidade de qualquer compromisso com a representação ou com qualquer atmosfera. Ao contrário, um reduzido grau de conhecimento técnico da aplicação da luz na cena já é suficiente, e basta contar com a ajuda de um técnico para instalar à frente do acontecimento espetacular tantos instrumentos (mais conhecidos como refletores) quanto necessários para iluminar (até que a cena se torne visível), e contar com o fornecimento contínuo de eletricidade até o final do espetáculo.

Até seria possível dizer que a promoção de visibilidade define a visualidade do teatro épico ou científico de Bertolt Brecht, já que a cena deveria ser exposta, banindo a representação realista do espaço, excluindo atmosferas, cores, ângulos e/ou texturas, usadas por outros diretores como solução para configurar o espaço realista ou simbólico da ação representada. Ou seja, o que torna a luz um aspecto consequente, em um espetáculo, não é o desejo de um crítico ou teórico. Importa, sim, a natureza do espetáculo em si. Bertolt Brecht afastaria do seu teatro, tanto a luz aplicada por Stanislavski, quanto aquela criada para um espetáculo de Robert (Bob) Wilson ou de Adolphe Appia. O discurso visual presente na obra de cada um dos artistas citados rejeitaria os caminhos considerados de excelência por outros. Aqui se identifica, por conseguinte, uma importante característica da luz efetivada na espetacularidade, ou seja, ela desempenha papel decisivo na elaboração do pensamento visual subjacente à cena ao interagir com as particularidades de cada espetáculo, construindo a natureza estético-poética - de uma montagem em 
si ou do conjunto da obra de determinado autor. Como explicitado no sumário a obra de Brecht será brevemente abordada no capítulo "A luz e a cena não realista."

\section{RELAÇÕES PRIMITIVAS ENTRE A HUMANIDADE E A LUZ}

O presente capítulo incorpora uma obra da dramaturgia, Nossa cidade (Our town), de Thornton Wilder (1897-1975), escrita em 1937, para introduzir a profundidade das primitivas relações entre a humanidade e a luz. A ação se passa nas duas primeiras décadas do século XX. Sem interesse na análise crítica da peça em si, será destacado o final do primeiro ato para considerar as relações entre o ser humano e a luz. ${ }^{27}$

É noite na cidade de Grover's Corners em New Hampshire, ao norte dos EUA; casa da família Gibbs; os irmãos Rebecca e George conversam ao final do dia, numa atmosfera de reflexão. Pode-se imaginar o quarto banhado por uma espécie da luz externa da noite, que entra pela janela. Logo, ambos se dirigirão às suas camas e, depois de uma noite de sono, como usualmente, recomeçarão a rotina de mais um típico dia da cidadezinha do interior. Rebecca comenta uma carta recebida por uma moradora local. De acordo com o remetente, a correspondência deveria ser entregue a Jane Crofut, cujo endereço seria: Fazenda Crofut, Cidade de Grover's Corners, Condado de Sutton, Estado de New Hampshire, Estados Unidos da América, Continente Norte-Americano, Hemisfério Ocidental, Planeta Terra, Sistema Solar, Universo, Mente de Deus.

Algum carteiro com maior pretensão científica poderia alegar que o endereço está incompleto, pois omitiu a Via Láctea. E até dispensaria o último detalhe, a Mente de Deus. Tal atitude poderia causar efeito traumático e conflito envolvendo carteiros cristãos. Ou até iluministas, que convocariam o seu deus, a razão. Isso, contudo, é tema de outro trabalho, que poderia ganhar tratamento particular de cada artista interessado em dramaturgia. Importa observar que, diante da diversidade de opiniões, se o endereço de Jane Crofut finaliza ou não em Deus - em meio às certezas da fé, ou, às dúvidas e especulações científicas - um detalhe não muda: ainda que more numa pequena cidade, de um dos menores Estados da América do Norte, ela está necessariamente ligada a um planeta que integra o Sistema Solar, cujo centro é apenas uma estrela, entre os prováveis quatrocentos milhões de estrelas da Via Láctea, o Sol. Ao fim e ao cabo, portanto, tudo se refere

27 Note-se que o termo dramaturgia ganhou aplicações diversificadas ao longo do século XX, aplicações essas cuja discussão será evitada aqui. 
a estrelas. Daí, a importância do texto de Wilder: tanto numa abordagem mística, quanto numa outra apoiada na experimentação científica, o endereço final - e primevo - de Jane Crofut, e do ser humano, é a luz.

Escritos religiosos, como as narrativas que originaram o cristianismo, há mais de uma dezena de séculos antes da era cristã, a tradição judaica, a civilização egípcia da Antiguidade, incorporaram e interpretaram a luz, sugerindo poder, fascinação e magia. As relações entre o ser humano e a luz percorrem a história da espécie há muito, despertando progressivo interesse. Na atualidade, quando os pesquisadores continuam a destituir fronteiras, o intuito de compreender a ação da luz sobre a presença humana no planeta, pode soar pretensiosa, bem como a intenção de refletir sobre as relações entre a luz e a práxis cênica, como um problema a ser investigado. Por outro lado, a busca por compreensão parece apontar a necessidade da discussão de tais relações, já que o conhecimento indica o enfrentamento de barreiras.

Pode-se resumir dizendo: iluminador é aquele que "faz a luz de uma peça". Tal assertiva, contudo, provoca questionamentos. Ao concluir a sentença, já se encontram razões para uma investigação, quando se leva em consideração que a luz artificialmente produzida pelo ser humano está ligada ao seu desejo de ampliar as relações com o ambiente, buscando substitutos para o sol e interferindo, inclusive, no conceito de tempo; são ampliadas as operações produtivas, assim como de lazer, entre outras, com a extensão (da luz) do dia. O ser humano emprega substitutos que, atuando de maneira relativa e parcial, buscam cumprir uma ou outra função da estrela.

Com o propósito de introduzir reflexões especificamente voltadas para a contribuição da luz à práxis cênica, vale antes sublinhar que ela é responsável pela construção de traços decisivos da natureza humana. Ao refletir acerca do seu próprio aparecimento e permanência no planeta, o ser humano depara-se, inevitavelmente, com o sol. Diante de tal constatação, o leitor pode presumir a amplitude do tema e compreender que o presente trabalho não pretende tratá-lo em profundidade. Ainda assim, dada sua importância ele não pode ser simplesmente ignorado, ou melhor, deve ser mencionado e, mesmo brevemente, comentado. Tais comentários podem ser considerados uma digressão, caso o leitor siga a tendência de observar superficialmente a luz aplicada à cena, considerando-a distante da investigação como procedimento sistemático.

O texto que se segue pode causar estranheza caso essa tendência seja mantida, encarando-se a luz como se ela representasse somente um apêndice necessário, sem conexões com o conhecimento, com a cultura. 
De todo modo, evitando detalhamentos que exigiriam o domínio de um especialista, é imprescindível registrar a presença do sol, da luz, na organização do sistema integrado pelo ser humano. É necessário, então, lembrar: a maior parte da energia que alimenta a Terra origina-se da fusão nuclear produzida no Sol, caracterizando sua interferência no conceito de humano. A humanidade estabeleceu-se no planeta de maior massa, dentre aqueles rochosos, o corpo celeste de maior densidade do seu sistema solar. Um corpo de tal dimensão depende de enorme equilíbrio para se manter vivo, funcionando. Da relação com seu único satélite natural - a lua - dependem muitos movimentos, inclusive a estabilidade de inclinação do seu eixo. A complexidade de tal relação só se amplia, quando o centro do sistema, o Sol, é levado em consideração.

Ainda que o total de dígitos necessários para quantificar a Terra seja enorme se comparado à escala humana, quando se envolve o Sol, nos termos aqui discutidos, toma-se consciência da dimensão relativa do ser humano. Desde Galileu (1564-1642), já se reconheceu que a humanidade não está no centro do sistema, posição ocupada por uma gigantesca esfera gasosa e brilhante. Não seria possível fazer qualquer ponderação acerca da luz, sem pontuar o núcleo da questão e/ou, sem sublinhar que a Terra se formou a partir de uma nuvem de poeira solar, agregando massa progressivamente, na forma granular de minérios atraídos pela força gravitacional.

Levem-se em consideração as cento e nove Terras que seriam necessárias para completar a circunferência do Sol, com um diâmetro de $1.392 .000 \mathrm{~km}$, e, em seu interior, caberiam 1,3 milhões de Terras. Trata-se, então, de uma estrela mais de uma centena de vezes maior que a Terra, constituída inteiramente de gás, cuja parte visível, do ponto de vista do nosso planeta, apresenta uma temperatura de 5.500 graus centígrados. Ativo há aproximadamente 4,5 bilhões de anos, o sol deve continuar brilhando por outros tantos bilhões de anos, quando, no fim de sua vida, começará a fundir o hélio em elementos mais pesados e se expandirá, finalmente, a uma proporção que engolirá a Terra, atraída para o seu interior. O que somente ocorrerá num ponto muito distante no futuro, dando algum tempo para que o ser humano reflita sobre a importância dessa estrela. A abordagem aqui encaminhada presume que, se alguém quer "fazer luz", deve considerar o mencionado contexto, o que já exige considerável esforço de pesquisa.

De modo simplificado, pode-se dizer que reações termonucleares ocorrem quando, no Sol, o hidrogênio, de que ele é basicamente constituído, é submetido a uma enorme pressão no interior da estrela e tem o seu núcleo fundido em temperaturas de até 15 milhões de graus Celsius, transformando-se em hélio. Parte 
da massa resultante é convertida pela fusão em energia, e, lançada no sistema solar, alcança a Terra, depois de filtrada pela própria atmosfera do planeta. Em tal processo, origina-se a principal fonte da energia que alimenta o planeta e permite o seu funcionamento, na condição de elemento constitutivo de um extenso sistema. A energia, na forma de luz solar, leva em torno de oito minutos e 18 segundos para percorrer a distância entre o Sol e a Terra, cerca de 150 milhões de quilômetros, onde é armazenada pelos seres vivos que, de variadas maneiras, dela dependem para sobreviver, inclusive no que se refere à manutenção da água em seu estado líquido. É importante dizer que, mesmo apresentando natureza diversificada, em diferenciadas extensões de ondas eletromagnéticas, a mais ampla manifestação da energia é a luz visível. A vida no planeta mantém, portanto, profundo compromisso com a visão.

Vale ponderar: aquilo que alguns chamam de realidade, o mundo visivelmente percebido, é fato do passado se considerarmos que o deslocamento da luz é mensurável no tempo. Isso determina que as imagens visuais percebidas pelo ser humano já ocorreram, quando ele registra sua presença. O que se considera presente, real, é sempre um acontecimento que se efetivou em um momento do passado, quando a luz incidiu sobre algo. A percepção humana só ocorre em alguma ocorrência temporal no futuro.

Cabe acentuar que tais observações não passam de um breve e superficial comentário e que os interessados na pesquisa acerca das relações entre a luz e a cena devem se debruçar sobre autores que discutem tais questões, estudando a temperatura termodinâmica, a radiação eletromagnética, o sistema Kelvin de mensuração, assim como diversificadas ramificações em determinadas áreas do conhecimento. Para o objetivo do trabalho que se segue, basta que se leve em conta a importância definitiva do Sol para a vida na Terra, alertando quem quer que se interesse pela luz a observá-lo com atenção.

Pode, então, parecer óbvio dizer que o ser humano interage com o Sol. O que interessa aqui, contudo, é sublinhar a íntima relação entre a humanidade e a maior estrela do sistema. É possível tratar das relações entre a luz e o pensamento, iniciando-se com o estudo dos gregos antigos, pesquisando sua exegese da visão, para investigar a construção humana do conhecimento ocidental.

Torna-se indispensável, entretanto, mencionar ações da humanidade que, anteriores a tal momento, provocam a abordagem do envolvimento do ser humano com a luz. De tais ações tomam parte antigas edificações, tão antigas a ponto de apresentarem dificuldade em sua datação ou até em sua função e autoria: as construções megalíticas. Nomeadas, aliás, a partir dos gregos: mega (grande, em grego) 
e lithó, pedra. Entre os megálitos mais famosos encontram-se a Grande Pirâmide de Khufu e o objeto da presente reflexão, Stonehenge (Figura 2).

Um complexo de pedras localizado na planície de Salisbury, no sul da Inglaterra, cuja construção é apontada por estudiosos em uma dilatada datação, entre 2.950 a.c. e 1.600 a.c., Stonehenge tem despertado grande interesse da ciência, envolvendo o trabalho de físicos, arqueólogos, astrônomos, arqueoastrônomos e estudiosos da história da arte. Impressiona quando se especula que tal complexo foi progressivamente modificado durante um período de quase 14 séculos, comprovando-se o interesse de sucessivos e diferentes momentos da humanidade pela edificação. Já se produziu grande diversidade de estudos acerca de Stonehenge - ou pedras suspensas, também chamadas trílitos - com interpretações que ligam o complexo a práticas religiosas, à observação astronômica e à tecnologia da construção.

Há grandes mistérios, no que se refere aos procedimentos aplicados para transportar e elevar blocos de pedras de 45 toneladas a 5 metros de altura, suscitando muitas questões. Em 1963, o arqueoastrônomo inglês e professor da Boston University, Gerald Hawkins (1928-2003), defendeu uma ideia que causou surpresa no ambiente científico. Ele afirmou, com base em pesquisa na qual já usou um computador transistorizado de segunda geração, o IBM 1970, usando recursos de pesquisa da Harvard University e do Smithsonian Institute, que a estrutura de pedras funcionou como observatório astronômico, como um dispositivo que interage com corpos celestes, permitindo, inclusive, a previsão de eclipses da Lua. Dois anos depois, Hawkins provocou reações muito adversas, quando comparou a estrutura a um sistema computacional, considerando-a uma espécie de computador neolítico, justificando suas conclusões na grande quantidade de cálculos que, segundo ele, podem ser efetivados usando-se as relações entre seus elementos arquitetônicos, o Sol e a Lua (Figura 3). Richard Atkinson (1920-1994), arqueólogo inglês, com pesquisas e escavações no sítio arqueológico de Stonehenge, desde a década de 1940, discordou veementemente de Hawkins.

Em 1966, Atkinson afirmou que os alinhamentos entre os elementos arquitetônicos da estrutura e o Sol, apontados por Hawkins, eram ilusórios, julgando imprecisas suas conclusões. É importante registrar que o interesse científico pelo lugar, contudo, já aparece desde o século XVIII, sempre se referindo à sua relação com a luz natural.

Interessa à presente abordagem sublinhar Stonehenge como presença na história humana, mesmo antes que qualquer pensamento sobre a intervenção da luz na Terra fosse registrado em um texto, ganhando cada vez mais atenção, ao longo 
dos últimos três séculos. Tendo despertado interesse de pesquisadores, vem sendo mencionado como complexo arquitetônico, obra importante da engenharia, observatório astronômico, monumento artístico e templo. Abordagens inevitavelmente relacionadas à luz, fazendo dele um dos mais antigos documentos-imagem acerca das relações entre o ser humano e a luz.

Na reconhecida trilha que inicia a construção do pensamento ocidental, as raízes gregas apontam a luz (phos) como o princípio de tudo (arché panton). Desde Zoé, a vida; nous, o pensamento; téchne, a arte; pólis, a cidade; episteme, o estudo da ciência ou da filosofia; poíesis, o fazer produtivo; pracsein, o agir; chrestai, o prestar. (LEÃO, 2010) Sua relevância para o homem grego pode ser assim expressa: “[...] luz é sempre energia irradiante em todo ser e não ser de tudo que é e está sendo, de tudo que não é nem está sendo. Energia de pura irradiação, a luz concentra em si a força poética do raio de Zeus, que rege e acata todas as coisas [...]". (DIELS apud LEÃO, 2010, p. 90)

Aqui interessa lembrar que a força de Zeus, no entanto, foi desafiada por Prometeu (dotado da antevisão), filho de Jápeto e Clímene, segundo Hesíodo; e de Têmis, segundo Ésquilo. Tinha três irmãos: Menécio, Atlas e Epitemeu (o que pensa depois).

Prometeu, o mais sábio entre eles, teria moldado o ser humano de argila e água (ou talvez com as suas lágrimas, numa versão poética, romântica). O homem moldado em barro recebeu vida dos ventos insuflados por Atena (Palas Atena). Durante o reinado de Cronos, homens e deuses eram igualmente tratados. Quando os deuses olímpicos tomaram o poder, Zeus os reuniu com representantes da humanidade para determinar que partes das vítimas dos sacrifícios deveriam ser entregues às divindades. Prometeu recebeu a incumbência de fazer a partilha de um boi entre deuses e humanos. De um lado, ele colocou carne e vísceras, do outro, ossos cobertos com toucinho reluzente e convidou Zeus para escolher. Preferindo o brilho da segunda opção e, descobrindo depois o truque, Zeus decidiu vingar-se. O brilho pode ser enganador; o opaco, a penumbra, por vezes, tem grande valor.

Em vários momentos da sua vida, Prometeu usou a astúcia para ajudar a humanidade, e teria roubado o fogo das rodas do carro do sol, para doá-lo ao ser humano. Prometeu estava presente quando Atena nasceu da cabeça de Zeus. Dela, ele recebeu ensinamentos de arquitetura, astronomia, matemática, navegação, medicina, metalurgia, entre outras artes, conhecimento que compartilhou com o ser humano.

Isso teria dado crescente poder e talento à humanidade, mas alimentou a raiva em Zeus, que decidiu aniquilar a raça humana, enviando Pandora (aquela que recebeu todos os dons), uma virgem de beleza única, moldada em barro, que recebeu 
de cada divindade um dom especial, incluindo a perfídia e os discursos enganadores, doados por Hermes. Pandora trazia consigo uma caixa, que se dizia conter maravilhas. Curiosa, abriu a caixa e espalhou males horrorosos sobre a Terra, mantendo apenas a esperança no seu interior. A ira de Zeus ainda não estava amainada e ele enviou o dilúvio para inundar a Terra. Deucalião, rei da Tessália e filho de Prometeu, aconselhado pelo pai, construiu uma embarcação e nela se protegeu acompanhado da mulher, Pirra.

A intervenção de Deucalião fez reinar a paz entre os homens e os deuses, mas Zeus não perdoou Prometeu, determinando uma dolorosa punição: ele ordenou que Hefesto, Crato e Bias acorrentassem Prometeu ao monte Cáucaso. Para completar o castigo, que durou 30 mil anos, uma águia devoraria seu fígado durante o dia que, crescendo durante a noite, seria comido no dia seguinte, destruindo de modo intermitente seu orgulho e revolta. Zeus finda por conceder perdão a Prometeu, que mais tarde seria imortalizado. Sua insurreição, contudo, já havia permitido ao ser humano a sabedoria originada no fogo (na luz).

Afinal, no dizer de Heráclito (ca. 535 a.c. - 475 a.c., o obscuro ou enigmático), o fogo, a luz, tem relações diretas com a vida. Por mais dessemelhanças que apresentem as inúmeras traduções e/ou comentários dos fragmentos de sua obra que, aliás, são fragmentos. Na versão de Heráclito para o inglês, Patrick (1889, p. 9o, tradução nossa) escreveu: "O homem acende uma luz para si durante a noite, quando ele está morto e vivo. Aquele que dorme, cuja visão foi retirada, ilumina de entre os mortos; ele, que está desperto ilumina desde o que dorme". ${ }^{28}$ Diante de inúmeras opções que se referem a acender, tocar, apagar, cuja discussão deixa ser objetivo da abordagem em curso, interessa a presença da luz nas referências à vida, à morte, à consciência, à vigília e ao sono (portanto, ao sonho).

Investigando as relações entre a luz (fogo) e a sabedoria, encontra-se também uma provocação significativa em uma imagem construída pelo texto bíblico, no Primeiro livro de Moisés, também chamado Gênesis: antes de tudo, Deus criou os céus e a terra. Até tal ponto, somente se toma conhecimento dos feitos do Senhor através da narrativa do evangelista mencionado; não há menções à luz, não se sentia sua falta; não era acentuada e, aparentemente, não existia. Tudo não passava de uma imagem mental?

A decisão divina parece fundamentar-se na precaução de refrear o envolvimento prematuro com a luz, tendo o cuidado de preservar os estágios preliminares do processo criativo, afastando problemas tão específicos, como aqueles

28 "Man kindles a light for himself in the night-time, when he has died but is alive. The sleeper, whose vision has been put out, lights up from the dead; he that is awake lights up from the sleeping." 
oriundos da intervenção contundente da luz. Daí, após a criação de terras, céus e águas - quando as trevas pairavam sobre a face do abismo - alcança-se o instante mágico de revelação da obra divina. Aquele ponto no qual um traço de união revelará, de modo substancial, o seu feito.

Um passo crucial, um momento para o qual tudo foi previamente preparado, exigindo procedimentos de excelência; Moisés, então, põe a si mesmo de lado e traz à cena o sujeito, dada a relevância do ato, deixando ao próprio Deus as palavras, aliás, suas primeiras palavras: "Fiat lux" (Gênesis, Capítulo 1, vers. 1/3). Da narrativa épica, passou-se ao drama, transformando a natureza do sujeito; agora há uma primeira pessoa que fala, não mais um narrador e, sim, a personagem que vivencia um conflito.

É importante mencionar Jó 1.6: "Num dia em que os filhos de Deus vieram apresentar-se perante o senhor, veio também Satanás entre eles" (BÍBLIA, 1999, p. 579), e destacar a nota teológica:

Seu nome significa 'adversário' [o que faz oposição a Deus e ao seu povo], e o Antigo Testamento o apresenta como tal (1 Cr 21.1; Jó 1-2; Zc 3.1-2]. [...] A esperteza enganadora de Satanás é realçada pela afirmação de Paulo, quando nos diz que Satanás transforma-se em anjo de luz, apresentando o mal como bem (2 Co 11.14) [...]. (BÍBLIA, 1999, p. 579)

Victor Hugo (1802-1885), por seu turno, aproxima-se da antiga cena, com a assertiva: "Jó começa o drama. E isso há quarenta séculos, pondo frente à frente Jeová e Satã; o mal desafia o bem e assim começa a ação; a terra é o palco, e o homem é o campo de batalha; os flagelos são as personagens". (HUGO, 2000, p. 41) ${ }^{29}$ Criação, drama e luz, portanto, há muito se tocam, se chocam e se transfiguram.

Considerando a Bíblia, tal interação é construída de modo robusto. Na sua Primeira Epístola, diz João: "Ora, a mensagem que, da parte dele temos ouvido, e vos anunciamos é esta: que Deus é luz, e não há nele trevas nenhumas”. (BÍBLIA, 1999, 1 João 1:5) Como observa Evgen Bavcar, a luz tornou-se a primeira imagem, a primeira imagem de Deus e a primeira presença no mundo. A revelação da natureza divina, entretanto, criou a primeira ausência, pois, como observa Bavcar (2005, p. 147), "[...] a face oculta do Eterno é tão luminosa que nos impede de ver claramente". Na verdade, a luz divina, ontológica, completa e integral, como descreve João, é um artifício de Deus para se tornar mistério: iluminando-se total e virtu-

29 "Job commence le drame, et il y a quarante siècles de cela, par la mise en présence de Jéhovah et de Satan; le mal défie le bien, et voilà Faction engagée. La terre est le lieu de la scène, et l'homme est le champ de bataille; les fléaux sont les personnages." 
almente, eliminando qualquer contraste estabelecido pelas sombras (trevas), ele torna-se invisível. Por outro lado, Deus cria o primeiro espetáculo, o mundo, habitado pela sua imagem e semelhança, e lança o pensamento oculicêntrico - ou ocularcêntrico -, mais tarde tão combatido como raiz do racionalismo, o primeiro "pecado" original divino.

Ainda que se possa discutir o que o termo luz significa, ao longo das inúmeras citações da Bíblia, ele aparece como sinal de dádiva, favores, justiça e sabedoria. Desde o Antigo Testamento, Salmo 4:6, lê-se: "Senhor, levanta sobre nós a luz do teu rosto". (BÍBLIA, 1999, p. 617) Trata-se de um rosto de luz, luz absoluta que se basta. Para difundir e confirmar a figura de Deus como fonte do conhecimento, santo Agostinho refere-se ao Salmo 36:9: "Na tua luz, veremos a luz". (BÍBLIA, 1999, p. 638) Tal conhecimento é dilatado para alcançar as hostes do contato com o sagrado, que acaba por indicar salvação.

Salvação que reside no Deus onisciente, com total domínio de sua semelhança, por ele mesmo projetada e inscrita na humanidade. O que é o Deus que não vejo, senão luz? Como não vejo, se é luz? Caso tivesse que se representar em imagem, Deus provavelmente projetar-se-ia como um sólido regular e desprovido de arestas. No limite da percepção visual humana, ele talvez fosse uma esfera, obviamente, também em semelhança ao "mundo". A esfera, no entanto, deveria ser concebida para evitar o sistema óptico do qual a humanidade foi provida. Deus, então, construiria a si mesmo como uma esfera, monocromática, opaca, (ou de polidez e brilho absolutos), iluminada virtualmente em cada um dos pontos visíveis, e colocar-se-ia num ambiente com o mesmo tratamento. Figura e fundo idênticos gerariam invisibilidade, ausência de referência corpórea ou material. Deus, somente e totalmente luz, tornou-se, portanto, invisível, uma ausência, uma instância de magia e crença.

No ato próprio de Deus, ao proferir a ordem que João acredita narrada por ele, expressa seu desejo através da palavra (Fiat lux!), fazendo nascer a imagem visual do mundo. Poder-se-ia afirmar que, também Deus, pensou visualmente, que ele construiu um discurso visual, ao criar sua ausência, desconstruindo a própria imagem, mas permitindo o equilíbrio na presença terrena do seu filho, respondendo à necessidade humana da visão. Na práxis cênica, nem mesmo as mais agudas revoluções propuseram a exclusão da imagem, o que pode provocar reflexões sobre a importância da mencionada "imagem visual", da imagem cênica e da visualidade como índices de sua natureza. A abordagem aqui encaminhada procura identificar como a natureza visual da práxis cênica propõe incorporações 
da luz ao pensamento que a provoca e cria, assim como à sua realização propriamente dita.

Mesmo que tais conexões causem estranheza, é importante acentuá-las, no presente estudo, para questionar a abordagem da luz como uma presença isolada, apenas funcional e inevitável, já que necessária para tornar a cena visível e atraente.

\section{CENA, LUZ E LUGAR}

A cena é irresistível; quando um romancista decide transgredir o espaço-tempo diegético do romance inserindo diálogos diretos - aqueles nos quais as personagens têm voz como discurso e proferem suas próprias palavras -, ele pode estar sendo atraído pelo teatro, como se desejasse ver sua obra em cena. Parece óbvio que, ao descrever ou narrar uma situação, o autor de um romance possa também estar abrindo portas para permitir à sua obra acesso ao palco, se esta for a vontade de um diretor, um coreógrafo, ou outro artista que decida levá-la à cena.

No texto dramático, contudo, as palavras constituem um estágio do processo rumo à cena, elemento indissociável de uma ação incorporada pela busca da realização de um desejo. Por esta razão, certas vertentes da crítica literária exclamam, ao falar de Racine, afirmando que sua poesia prescinde do palco. O termo exclamar é usado aqui para denotar a força da reação diante da possibilidade de um diálogo que se basta e desconsidera o palco. A cena latente na dramaturgia será impregnada de cores, formas e texturas, revelando na práxis cênica visões brotadas da leitura de um diretor que, por sua vez, empregará sua capacidade de provocar a equipe de um espetáculo para subverter caracteres alfabéticos impressos numa página, elaborando o conjunto de imagens que delinearão um pensamento visual para a cena.

Depois de tentar, por duas vezes, retirar os sapatos, como num jogo, Estragon diz: "Nada a fazer", ${ }^{\circ}$ primeira fala de Esperando Godot (En attendant Godot), de Samuel Beckett, estreada em 1953. Considerando que Beckett escreveu para o teatro e, mesmo levando em conta a força sonora das palavras, pode-se buscar a ação da qual a fala é apenas um dos aspectos. Uma assertiva de tal natureza pode sugerir, numa leitura superficial, que Estragon propõe a imobilidade: não há nada que se possa fazer. Ou seja, estaria abolida a ação e, consequentemente, o teatro, o acontecimento espetacular. Na constatação de Estragon, no entanto, reside uma ação contundente, uma deliberação vigorosa. Leia-se: eu preciso aniquilar o silêncio! 
Beckett escolheu de modo competente uma expressão muito dura para caracterizar a impotência que se instalará no seu drama, diante da espera sem perspectivas. Como uma situação de grave crise, a impotência opera aqui no nível dramático para, mesmo diante da iminência de estagnação, da paralisia, provocar a ação. Para Estragon, o contato com o outro é vital; ele, então, provoca Vladimir, caracterizando um desejo - e a ação que decorre de um desejo - e, portanto, um lugar onde a ação ocorre. O desejo faz de um espaço um lugar tocado por almas. A elaboração cênica de tal acontecimento resulta e se efetiva em imagens. Inclusive materiais. No contexto teatral, cênico, sem luz o processo não se completa, o objeto artístico deixa de existir.

Diante disso, manter a luz fora da sua obra transformar-se-ia numa tarefa hercúlea para um dramaturgo; a menos que ele exclua a ação, o ser humano, seus desejos e reações. Inclusive o seu próprio, o desejo de revelar sua obra corporificada no espaço teatral. Portanto, ao gerar na imaginação as primeiras ideias (idein, em grego, forma, padrão), as primeiras personagens da sua trama - cujos desejos serão selecionados para garantir a eficiência - o autor teatral estará incorporando luz ao seu trabalho. Mesmo que o faça intuitivamente. Será chocante para um antagonista de tal assertiva observar que ela é imune aos limites dos estilos, das escolas, das poéticas, das estéticas, das vanguardas, do "anti" e do "pós", qualquer que seja o modelo questionado. Enquanto tratar-se de práxis cênica, lá estará a luz. Assim como a sombra. E vale lembrar as iniciativas que investem na iluminação em si, como objeto da provocação espetacular.

No contexto do estudo da luz como elemento da espetacularidade se inclui, desde um dramaturgo com décadas de experiência que esteja escrevendo uma peça encomendada para ser levada ao público em um chamado "palco italiano", configurando-se no mais tradicional espetáculo, até um jovem artista (não mais denominado ator e conhecido talvez como performer), movido pelo desejo de realizar uma ação diante de, pelo menos, uma pessoa - espectador, fruidor, ou outra denominação variante das diversificadas tendências estéticas -, em qualquer que seja o espaço, que pode ser uma via pública ou um shopping mall, como exemplos, - sem qualquer compromisso com o drama, ou até com a palavra. Se alguém comparecer ao local determinado pelo artista para compartilhar com ele o evento e, durante a performance, tiver a chance de ver o acontecimento, mesmo que seja por uma pequena fração de tempo, estará efetivada a presença da luz. Mesmo que o autor do acontecimento exclua deliberadamente o adjetivo cênico, a personagem, o conflito, ainda assim, ele não será capaz de excluir o seu desejo 
de se constituir como um corpo transfigurado em imagem visual. Para realizar tal desejo, ele necessitará da luz.

O interesse da presente discussão indica uma consideração: mesmo que se trate de um pequeno instante de luz, ele terá grande relevância, até mesmo porque a redução e/ou o isolamento acentuará sua presença na composição visual da cena. Para explicitar: um evento em total escuridão que inclua um fragmento de luz, o tornará um momento único. E mais, em geral, num evento cênico, a incorporação da luz pode ser tão contundente a ponto de fazer o espectador considerar os momentos de black-out (na cena, escuridão esteticamente deliberada, definida pela retirada de toda luz artificial) como uma ausência momentânea de luz e não a presença da escuridão. Isso pode parecer vantagem. A longa permanência da luz na cena pode, contudo, transformar-se em armadilha, ou seja: ela pode ser aplicada de modo generalizado, atendendo a fórmulas fáceis e/ou efeitos superficiais.

A luz lembra uma praga. Negligenciada, poderá se instalar e agir como uma maldição milenar. O iluminador tem a oportunidade, alguns diriam o dever, de tratar cuidadosamente de cada detalhe do seu trabalho e, mesmo num pequeno momento da cena, todos os artistas envolvidos reúnem-se em uma única pessoa, o performer, lidando inevitavelmente com a luz. Daí, cada pequeno instante exigirá grande atenção daquele artista que respeita integralmente a obra, que não aceita superficialidades sem função estética. Mesmo que se imponha um instrumento de corte, como a cortina ou o black-out, isso exige enorme atenção e precisão na elaboração da luz.

Recebendo atenção e sendo aplicada com discernimento, a luz pode passar de praga à dádiva, uma vez que coloca à disposição do artista um conjunto de instrumentos, acessórios e procedimentos, capazes de contribuir positivamente na realização do seu espetáculo. Alcançando tal ponto, seria bom interagir com uma teoria e uma crítica fundamentadas que reconheçam as diferenças.

Estudando as fontes mais antigas que tratam da luz teatral pode-se encontrar, surpreendentemente, já nas atividades consideradas mais incipientes do teatro, uma série de considerações teóricas, críticas e artísticas, que antecipam questões encontradas também em textos da atualidade. Muitos textos antigos estão relacionados a uma abordagem utópica da cena, projetando uma categoria de espetáculo apenas imaginada ou desejada.

Os próximos capítulos destacam e comentam importantes documentos do mencionado corpo teórico, crítico e artístico consultado, sob o ângulo das relações entre a luz e a práxis cênica. 